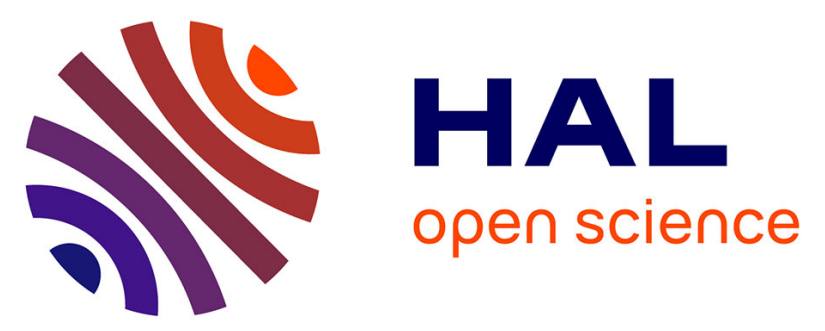

\title{
The safety of medications used to treat peripheral neuropathic pain, part 1 (antidepressants and antiepileptics): review of double-blind, placebo-controlled, randomized clinical trials
}

Marie Selvy, Mélissa Cuménal, Nicolas Kerckhove, Christine Courteix, Jérôme Busserolles, David Balayssac

\section{To cite this version:}

Marie Selvy, Mélissa Cuménal, Nicolas Kerckhove, Christine Courteix, Jérôme Busserolles, et al.. The safety of medications used to treat peripheral neuropathic pain, part 1 (antidepressants and antiepileptics): review of double-blind, placebo-controlled, randomized clinical trials. Expert Opinion on Drug Safety, 2020, 19 (6), pp.707-733. 10.1080/14740338.2020.1764934 . hal-02997564

\author{
HAL Id: hal-02997564 \\ https://hal.uca.fr/hal-02997564
}

Submitted on 10 Nov 2020

HAL is a multi-disciplinary open access archive for the deposit and dissemination of scientific research documents, whether they are published or not. The documents may come from teaching and research institutions in France or abroad, or from public or private research centers.
L'archive ouverte pluridisciplinaire HAL, est destinée au dépôt et à la diffusion de documents scientifiques de niveau recherche, publiés ou non, émanant des établissements d'enseignement et de recherche français ou étrangers, des laboratoires publics ou privés. 
The safety of medications used to treat peripheral neuropathic pain, part 1 (antidepressants and antiepileptics): review of double-blind, placebocontrolled, randomized clinical trials

\section{Authors}

Marie Selvy ${ }^{1}$, Mélissa Cuménal ${ }^{2}$, Nicolas Kerckhove $^{3}$, Christine Courteix ${ }^{2}$, Jérôme Busserolles $^{2}$, David Balayssac ${ }^{1}$

1. Université Clermont Auvergne, CHU Clermont-Ferrand, INSERM U1107 NEURO-DOL, Clermont-Ferrand, F-63000 Clermont-Ferrand, France.

2. Université Clermont Auvergne, INSERM U1107 NEURO-DOL, Clermont-Ferrand, F63000 Clermont-Ferrand, France.

3. Université Clermont Auvergne, CHU Clermont-Ferrand, INSERM U1107 NEURO-DOL, Institut Analgesia, Clermont-Ferrand, F-63000 Clermont-Ferrand, France.

\section{Corresponding author}

David Balayssac

INSERM U1107, NEURO-DOL

Laboratoire de Toxicologie, UFR de Pharmacie

28, place Henri Dunant, 63000 Clermont-Ferrand, France

Phone : +33473178041

dbalayssac@chu-clermontferrand.fr 


\title{
The safety of medications used to treat peripheral neuropathic pain, part 1 (antidepressants and antiepileptics): review of double-blind, placebo- controlled, randomized clinical trials
}

\author{
Introduction \\ Peripheral neuropathic pain is highly disabling conditions for patients and a challenge \\ for neurologists and pain physicians. Although many drugs have been assessed in \\ scientific studies, few have demonstrated a clear clinical efficacy against neuropathic \\ pain. Moreover, the paucity of data regarding their safety raised the question on the \\ benefit-risk ratio when used in patients experiencing peripheral neuropathies.
}

\section{Areas covered}

We conducted a review of double-blind, placebo-controlled, randomized clinical trials to assess the safety of medications used to treat neuropathic pain. This first review was focused on antidepressant and antiepileptic medications. The aim was to provide an overview of the treatment-emergent adverse events $(\geq 10 \%)$ and the serious adverse effects described in clinical trials.

\section{Expert opinion}

Among antiepileptics and antidepressants, duloxetine appeared to have the most detailed safety for the treatment of peripheral neuropathic pain. Over all studies, the most commonly reported adverse effects were dizziness, drowsiness, nausea, and constipation. Only $20.0 \%$ of the included studies $(\mathrm{N}=90)$ presented a good description of adverse effects that included a statistical comparison versus a placebo group.

Important methodological improvements must be made to improve the assessment of medication safety in future clinical trials.

Keywords: drug-related side effects and adverse reactions; neuropathic pain; randomized controlled trials; peripheral nervous system diseases 


\section{Introduction}

Sensitive peripheral neuropathy and its most disabling symptoms, neuropathic pain, refers to a lesion or disease of the somatosensory nervous system [1]. Peripheral neuropathy can be classified as a mixture of phenomenological, neurophysiological, pathological, and etiological parameters [2]. The most common form of peripheral neuropathy is chronic axonal lengthdependent sensorimotor polyneuropathy. Neuropathic symptoms can be divided into sensory and motor symptoms. The sensory symptoms include tingling, pins/needles, numbness, tightness, burning, pain, and sensory ataxia. Motor symptoms include muscle cramps, stiffness, weakness, and wasting [3]. Peripheral neuropathy may result from various conditions, including traumatisms (e.g., amputation, surgery, nerve compression), diabetes, toxicants (e.g., neurotoxic drugs, lead, alcohol), and infectious agents (e.g., herpes zoster, leprosy) [4].

The prevalence of neuropathic pain in the general population is approximately $6.9 \%$ 10\% [5-7]. According to IASP (International Association for the Study of Pain), chronic neuropathic pain can be divided in two subgroups, central neuropathic pain and peripheral neuropathic pain [8]. However, in a cohort of Spanish patients with neuropathic pain, only $12.9 \%$ had a pure peripheral neuropathic pain. Most patients with peripheral neuropathy do not develop neuropathic pain. In patients suffering from diabetic peripheral neuropathy, $21 \%$ of patients presented neuropathic pain symptoms. However, the prevalence of neuropathic pain increased to $60 \%$ in those with severe clinical neuropathy [9]. The same results have been found for patients suffering from oxaliplatin-induced peripheral neuropathy [10].

In 2016, the Neuropathic Pain Special Interest Group (NeuPSIG) from the International Association for the Study of Pain (IASP) performed a meta-analysis of randomized, double-blind clinical trials (RCTs) assessing medications for the treatment of neuropathic pain [11]. The NeuPSIG presented strong recommendations for gabapentin, 
gabapentin-extended release/enacarbil, pregabalin, serotonin and noradrenaline reuptake inhibitors (SNRIs), duloxetine/venlafaxine, and tricyclic antidepressants (TCAs), which were recommended as first-line therapies, and weak recommendations for $8 \%$ capsaicin and lidocaine patches, tramadol, botulinum toxin-A (subcutaneous), and strong opioids, which were recommended as second- or third-line therapies [11]. In addition to these recommendations, the NeuPSIG highlighted the safety and tolerability of these medications, which was low to moderate for TCAs, tramadol, and strong opioids; moderate for the SNRIs duloxetine and venlafaxine; moderate to high for pregabalin, gabapentin, gabapentin extended release/enacarbil and capsaicin 8\% patches; and high for lidocaine patches and botulinum toxin-A (subcutaneous) [11]. Consequently, most of the recommended medications for the treatment of neuropathic pain had moderate safety and tolerability, underlining that in addition to the difficulty of identifying effective treatments for neuropathic pain, the safety of these treatments is a concern [11]. It should be noted that chemotherapy-induced peripheral neuropathy (CIPN) is a special case. Indeed, the American Society of Clinical Oncology (ASCO) recommendations for the prevention and the management of CIPN suggested that there was no agent recommended for the prevention of CIPN [12]. For the treatment of CIPN, the available data indicate only a moderate recommendation for duloxetine. Authors of these recommendations also underlined the paucity of data available on adverse events in clinical trials [12].

The aim of this review was to assess the safety profile of medications used to treat peripheral neuropathic pain. This first review was focused on antidepressant and antiepileptic medications. 


\section{Methods}

\subsection{Protocol}

The protocol of this review was not registered. The safety of medications used to treat peripheral neuropathic pain has been assessed based on results from clinical trials assessing medications compared with a placebo, and a randomized double-blind design.

\subsection{Eligibility criteria}

A bibliographic search was performed to extract original articles on clinical trials assessing antidepressant and antiepileptic medications for the treatment of peripheral neuropathic pain.

The inclusion criteria were established to meet the following PICOS items: patients without limit of age, patients with peripheral neuropathic pain, treated by antidepressant or antiepileptic medications (single therapy and chronic treatment for at least 1 week), compared with a placebo, and a randomized double-blind design. No specific outcome was defined for the inclusion criteria, whatever the description of treatment-related adverse events was. Studies were included and analyzed only if the full-text was available and in English.

The exclusion criteria specified restrictions on publication types (exclusion of reviews/meta-analyses, letters to the editor, study protocols, and case reports/case series), therapeutic assessments (exclusion of pathophysiology and epidemiology studies in the fields of neurology, oncology, endocrinology, infectious disease, rheumatology, preclinical studies), and medication assessments (exclusion of massage, acupuncture, electrostimulation, and physical activity, meditation, and cognitive strategies). Studies were excluded if they were focused on central pain or pain other than peripheral neuropathic pain. Studies assessing pharmacokinetic parameters and drug combinations, Phase 1 trials, and healthy volunteer trials were excluded. 


\subsection{Information sources and search}

A bibliographic search of the PUBMED database (www.ncbi.nlm.nih.gov/pubmed) was performed. Two data extractions have been done on the same time frame (01/01/200013/02/2019). The first data extraction, focused on peripheral neuropathy, was performed with the following keywords "peripheral neuropathy" and PUBMED filters: clinical trials, human, and English. The second data extraction, focused on neuropathic pain, was performed with the following keywords sequence ((((“neuropathic pain”) AND randomized) AND controlled) NOT mice[Title]) NOT rats[Title] and PUBMED filter for "English" and "excluding review". All duplicate publications were removed between the first and the second extraction. The literature analysis was limited to the publications extracted from PUBMED.

\subsection{Study selection}

All PUBMED study identification numbers (PMID) were extracted from PUBMED and collated in Zotero software (Roy Rosenzweig Center for History and New Media) to create a Zotero bibliographic database including the following details for each publication: authors, title, journal, year, and abstract. This Zotero bibliographic database was thereafter extracted to Excel software (Microsoft) for analysis. An initial publication selection based on title and abstract was performed by authors NK and DB. After this first study selection, all authors performed a second study selection based on the publication full-text and in accordance with the inclusion/exclusion criteria. If a discrepancy with respect to the inclusion/exclusion criteria was noted for a publication, a consensus between authors was sought on whether to include or withdraw the publication.

\subsection{Data collection process and data items}

The full-text of the selected studies was analyzed and the following items were collected: 
authors' names, study design, drug/comparator, drug dose, number of patients, duration of treatment, type of peripheral neuropathy, description or not of treatment-emergent adverse events (TEAEs), list of TEAEs in study drug arm ( $\geq 10 \%$ of patients), statistical comparison of TEAEs between groups, serious adverse events (SAEs) related to the study drug, dropout rate due to TEAEs in study drug arm, drug efficacy and PMID.

\subsection{Risk of bias in individual studies and across studies}

No risk of bias was assessed across the included studies. However, the quality of the safety assessment was considered and discussed in the overall analysis of the studies.

\subsection{Summary measures and synthesis of results}

The analyzed items were collected and presented in synthetic and harmonized tables by pharmacological classes and international non-proprietary names. All the cited adverse effects and statistical analyses (p-values) were derived from the included studies.

\section{Results}

Among the 2148 identified publications, 92 publications describing double-blind, placebocontrolled, randomized clinical trials of antidepressant and antiepileptic medications were identified. Two full texts were not available and, overall, 90 publications were included and analyzed in this review (Figure 1).

Based on the selected publications, the following medications have been assessed:

- Antiepileptics: gabapentinoids: gabapentin, pregabalin and mirogabalin (Table 1); other antiepileptics: lamotrigine, lacosamide, levetiracetam, valproate, zonisamide, ethosuximide, carisbamate, oxcarbazepine and carbamazepine (Table 2). 
- Antidepressants (Table 3): serotonin and noradrenaline reuptake inhibitors (SNRIs): duloxetine, venlafaxine and milnacipran; tricyclic antidepressants (TCAs); escitalopram.

\subsection{Antiepileptics}

The use of antiepileptic drugs has increased the last decade, mainly because of increased utilization in indications other than epilepsy such as neuropathic pain and psychiatry. Antiepileptic drugs are strongly associated with TEAEs, which may lead to early discontinuation of treatment (and account for almost $25 \%$ of all discontinuation of antiepileptic drug treatment) and non-adherence, and impact the quality of life of patients $[13,14]$. In addition, TEAEs are one of the most common causes of treatment failure $[13,15]$. Thus, careful safety considerations for each individual patient are crucial for the optimal treatment outcome.

\subsubsection{Gabapentinoids}

Gabapentinoids are a class of drugs that are derivatives of the inhibitory neurotransmitter $\gamma$ aminobutyric acid (GABA), which block the $\alpha 2 \delta$ subunit of voltage-gated calcium channels (VGCCs) [16]. Commonly used gabapentinoids include gabapentin, pregabalin, mirogabalin, and gabapentin enacarbil (gabapentin prodrug).

3.1.1.1 Gabapentin. Gabapentin is mainly used for the treatment of partial seizures, neuropathic pain, hot flashes, and restless leg syndrome [17]. Gabapentin, discovered by Parke-Davis in 1975, was patented in 1977 and its medical use was first authorized in the United States in 1993 [18]. Gabapentin, via $\alpha 2 \delta$ calcium channel subunit inhibition [16,19], exerts antiepileptic, analgesic, and anxiolytic effects [19], and it is marketed and genericized under various names (e.g. Neurontin $($ ). The wholesale price of gabapentin the developing 
world as of 2015 was approximately US $\$ 10.80$ per month, and in 2016 , it was the $11^{\text {th }}$ most prescribed medication in the United States, with more than 44 million prescriptions [20]. For the treatment of chronic pain, gabapentin is recommended as a first-line medication (among others) for neuropathic pain mainly caused by diabetic neuropathy and postherpetic neuralgia [21]; however, evidence of its efficacy on other types of neuropathic pain remains very limited [22].

The 15 RCTs included in our analysis included 2553 patients: 1604 received oral gabapentin or placebo. The daily dose of gabapentin administered was from 300mg to $3600 \mathrm{mg}$, for a treatment duration from 10 days to 98 days, in patients with various neuropathic pain. The number of positive studies (analgesic efficacy of gabapentin compared to placebo) was only 5 (33.3\%), and the effects were mainly modest. This was consistent with the last Cochrane meta-analysis, which demonstrated the limited efficacy of gabapentin on neuropathic pain [22]. Multiple TEAEs were observed, in $46.9 \%$ to $82.0 \%$ of patients (among the six studies that evaluated the overall frequency) reported at least one TEAE associated with gabapentin (of which $0.0 \%$ to 5.0 were considered serious), leading to dropouts in 0.0 to $18.0 \%$ of cases. The main TEAEs observed were dizziness (10-37.3]) and drowsiness (10.087.5]) (Table 1). In the six studies that reported the SAE occurrence, the gabapentin-related SAEs were gastritis and fainting episodes. It was observed that the safety assessment of gabapentin was not performed in two studies, and that four studies did not assess the frequency of TEAE occurrence (9 SAEs). Among the four studies that compared different doses or dosing regimens, we found no difference in the type (dizziness and drowsiness) and frequency of TEAE occurrence (46.9-82.0\%). In addition, 13 studies (87.0\%) did not statistically compare the frequencies of appearance of TEAEs with placebo, making it impossible to determine whether the TEAEs observed were indeed related to gabapentin. In the two studies that statistically compared TEAEs with placebo, one showed no difference 
and the second showed that only dizziness, drowsiness, and lethargy were more frequent. This was consistent with the summary of product characteristics (SPC) for gabapentin, which described common TEAEs related to gabapentin, including drowsiness and dizziness [17]. Recently, gabapentin was also shown to induce abuse and addiction disorders, affecting $1.1 \%$ of the general population and $22.0 \%$ of the population in drug abuse treatment centers [23]. Withdrawal syndromes also exist, and occurred following discontinuation of the medication [23]. Finally, the misuse of gabapentin has been recorded for a number of reasons, including self-medication, self-harm, and recreational use [24]. Indeed, the misuse and abuse of gabapentin, known on the streets as "Gabbies," for its euphoric effects is increasing [25].

3.1.1.2 Pregabalin. Pregabalin is used to treat epilepsy, neuropathic pain, fibromyalgia, restless leg syndrome, and generalized anxiety disorder [26,27]. Pregabalin was invented and synthesized in 1990, as an antiepileptic, by Richard Bruce Silverman. Pregabalin and gabapentin had similar affinities for the human recombinant $\alpha 2 \delta-1$ subunit, although a study showed that pregabalin possessed six-fold higher affinity for the $\alpha 2 \delta$ subunit than gabapentin [28]. Pregabalin is more potent than gabapentin as an analgesic and an antiepileptic [29,30]. Pregabalin, developed as a successor to gabapentin, was first approved in the United States in 2004. Pregabalin is recommended as a first-line medication for the treatment of chronic pain related to diabetic neuropathy, post-herpetic neuralgia, and central neuropathic pain [21], but its use for sciatica and low back pain [31,32], cancer-related pain [33], migraine [34], and prevention of post-surgical chronic pain $[35,36]$ is controversial.

Our analysis included 38 RCTs representing 8739 patients: 4771 received oral pregabalin or placebo. The daily dose of pregabalin administered was from $75 \mathrm{mg}$ to $600 \mathrm{mg}$ ], for a treatment duration from 7 days to 1380 days, in patients with various neuropathic pain. The number of positive studies (analgesic efficacy of pregabalin compared to placebo) was 20 
(53\%), and the effects were mainly modest. This was consistent with the recent Cochrane meta-analysis, which concluded that "Evidence shows efficacy of pregabalin in postherpetic neuralgia, painful diabetic neuralgia, and mixed or unclassified post-traumatic neuropathic pain, and absence of efficacy in HIV neuropathy; evidence of efficacy in central neuropathic pain is inadequate. Some people will derive substantial benefit with pregabalin; more will have moderate benefit, but many will have no benefit or will discontinue treatment” [37]. As for gabapentin, multiple TEAEs were observed and their frequencies were similar: 7.0-85.8\% of patients (among the 24 studies that evaluated the overall frequency) reported at least one TEAE associated with pregabalin (including 0.0 to $10.4 \%$ considered serious among the 15 studies that evaluated them), causing from 0.0 to $21.1 \%$ of dropouts. Similar to gabapentin in terms of types and frequencies, the main TEAEs observed were dizziness (10.1-46.0\%) and drowsiness (10.5-40.0\%) (Table 1). In the 15 studies that reported the frequency of occurrence of SAEs, pregabalin-related SAEs were dyspnea and nausea, suicidal thoughts, tremor, and ventricular extrasystoles. The safety assessment was not performed in one study, and six studies did not assess the frequency of AE occurrence (20 for SAEs). Among the seven studies that compared different doses or dosing regimens, there appeared to be a relationship between dose and frequency of occurrence of TEAEs. Daily doses of 150, 300, and $600 \mathrm{mg}$ induced dizziness (11.1\% [95\% CI: 5.1\%-18.1\%], 27.6\% [95\% CI: $16.6 \%$ $38.6 \%$ ], and $37.3 \%$ [95\% CI: $29.3 \%-45.3 \%$ ], respectively) and drowsiness (0.0\% [95\% CI: $0.0 \%-7.0 \%$ ] $17.4 \%$ [95\% CI: 8.4\%-26.4\%], and 23.8\% [95\% CI: $12.8 \%-34.8 \%$ ], respectively). Only one study statistically compared the frequencies of TEAE with placebo, making it impossible to determine whether the observed TEAEs were indeed related to pregabalin [38]. In this study, only dizziness occurred more frequently. Overall, the safety profiles observed were consistent with the SPC of pregabalin, which describes common TEAEs related to pregabalin, including drowsiness and dizziness, and SAEs, including an 
increased risk of suicide and drug reactions. Finally, pregabalin can induce withdrawal symptoms following abrupt or rapid discontinuation, and recent studies have reported the risk of abuse, misuse, dependence, or overdose following the use of pregabalin [25].

\subsubsection{Mirogabalin. Mirogabalin was developed by Daiichi Sankyo. As with other} gabapentinoids, mirogabalin binds to the $\alpha 2 \delta$ subunit of VGCCs, but with a significantly higher potency than pregabalin. Mirogabalin was approved in 2018 in Japan for the treatment of peripheral neuropathic pain. Clinical development of the drug for fibromyalgia treatment was discontinued in the United States and Europe after the primary endpoint was not met in Phase 3 trials [39].

Only three RCTs evaluated mirogabalin for neuropathic pain treatment, comprising 1,721 patients with diabetic peripheral neuropathic pain: 1,061 received mirogabalin or placebo. The daily dose of mirogabalin was from $5 \mathrm{mg}$ to $30 \mathrm{mg}$, and the duration was from 35 days to 98 days. All studies were positive for the treatment of diabetic peripheral neuropathy; however, further studies are needed to evaluate its therapeutic effect on other types of neuropathic pain. Only the study of Merante et al. evaluated the percentage of subjects reporting at least one TEAEs, with $10.9 \%$ for mirogabalin $5 \mathrm{mg}, 19.6 \%$ for mirogabalin $10 \mathrm{mg}, 26.4 \%$ for mirogabalin $15 \mathrm{mg}, 19.6 \%$ for mirogabalin $20 \mathrm{mg}$, and $28.1 \%$ for mirogabalin $30 \mathrm{mg}$ [40]. The commons TEAEs identified by the three studies were dizziness, drowsiness, and headache ( $<10 \%$ of patients). From $0.0 \%$ to $2.9 \%$ of SAEs were observed (Table 1). Only one study performed a statistical comparison of the frequencies of appearance of TEAEs between treatment and placebo, making it impossible to determine whether the TEAEs observed were indeed related to mirogabalin. In this study, only drowsiness occurred more frequently. However, the number of studies is too small to show a difference between the different doses in terms of TEAEs frequencies. Finally, concerning the 
risk of abuse and misuse, the recent study of Mendell et al. concluded that "This indicates therapeutic doses mirogabalin may have less abuse potential versus diazepam or pregabalin. At supratherapeutic doses $(\geq 4 \times$ therapeutic dose), mirogabalin had significantly higher Drug Liking $E_{\max }$ than placebo, but lower $E_{\max }$ than pregabalin. In both studies, therapeutic doses of mirogabalin demonstrated limited evidence of abuse potential." [41].

\subsubsection{Other antiepileptics}

3.1.2.1 Lamotrigine. Lamotrigine (Lamictal ${ }^{\circledR}, \mathrm{GSK}$ ) is a phenyltriazine derivative that is believed to inhibit the release of excitatory neurotransmitters, particularly glutamate and aspartate. It also acts directly on neuronal ion channels, inhibiting several voltage-gated sodium channels [42] N-(Cav2.2), P/Q-(Cav2.1), and R-type (Cav2.3) [43]. Lamotrigine was approved for epilepsy in the United States in 1994 and it is still commonly used. It is indicated for the prevention and management of partial and generalized seizures either alone or in combination with other antiepileptic agents. Lamotrigine is also approved for use as a mood stabilizer in bipolar disorders. It is used off-label for several other conditions, including peripheral neuropathy, neuropathic pain, migraine headaches, and trigeminal neuralgia. However, very slow titration of the drug is required to avoid the development of rash. Lamotrigine is on the World Health Organization's List of Essential Medicines, which comprises the most effective and safest medicines needed in a healthcare system.

The three RCTs included in our analysis included 572 patients: 189 of whom received oral lamotrigine or placebo (Table 2). In all datasets, the maintenance daily dose of study medication in the lamotrigine groups was between 300 and $600 \mathrm{mg}$, inclusive, for a treatment duration from 10 to 14 weeks in patients with various neuropathic pain. The number of positive studies (analgesic efficacy of lamotrigine compared with placebo) was only 1 (33.3\%). The most common TEAEs were rash, infection, diarrhea, nausea, and headache, and 
the frequency of dropouts induced by TEAEs was from $6.7 \%$ to $24.0 \%$. Only the study of Silver et al. evaluated the frequency of total TEAEs, with $71.0 \%$ of patients receiving lamotrigine experiencing at least one TEAE (0.0\% SAE) [44]. There was no statistical comparison of the incidence of TEAEs between the treatment and placebo in these three studies. In the SPC of lamotrigine, the dose-related TEAEs included dizziness, blurred vision, diplopia, unsteadiness, nausea and vomiting, headache, and tremor. Stevens-Johnson syndrome, toxic epidermal necrolysis, hypersensitivity syndrome, suicide, and hemophagocytic lymphohistiocytosis were SAEs. The number of studies was too small to show a difference between the different doses in terms of TEAEs frequencies.

\subsubsection{Lacosamide. Lacosamide, discovered by Harold Kohn, Shridhar Andurkar, and} colleagues at the University of Houston in 1996 [45], is indicated as monotherapy and adjunctive therapy for focal seizures and for diabetic neuropathic pain. Lacosamide blocks sodium channels, enhancing slow inactivation, unlike most classic sodium channel blockers, which enhance fast sodium channel inactivation.

In five RCTs, lacosamide (100-600 mg/day) was used for from 7 to 18 weeks in patients with diabetic neuropathy in four multicenter studies and in patients with Nav1.7related small fiber neuropathy in one single-center study (Table 2). The safety and efficacy analyses from these studies indicated that lacosamide provided a moderate balance between efficacy (four of the five studies showed positive results) and TEAEs both in patients with diabetic neuropathy and with Nav1.7-related small fiber neuropathy. The proportion of patients that experienced TEAEs that were considered by the investigators to be at least possibly related to trial medication was from $58.7 \%$ to $89.2 \%$ whatever the dose. In these studies, the most frequent TEAEs following lacosamide treatment were dizziness (10.8$41.7 \%$ ), and nausea (11.3-25.0\%). Nevertheless, none of the five studies performed statistical 
comparison of the frequencies of TEAE occurrence with the placebo group, making it impossible to determine whether the TEAEs observed were indeed related to lacosamide. SAEs (occurring from $4.2 \%$ to $8.3 \%$ of patients in the studies they were evaluated in) were considered unrelated or unlikely to be related to trial medication by the investigators. Among the three studies that compared different doses or dosing regimens, no difference in the type (dizziness and nausea) and frequency of TEAEs were reported in the publications. In the SPC of lacosamide, the most common TEAEs described are dizziness, headache, nausea, vomiting, diplopia, fatigue, and sedation, all of which were more common at higher doses.

3.1.2.3 Levetiracetam. Levetiracetam is the $(S)$-enantiomer of the ethyl analog of piracetam. It is a well-tolerated widely used antiepileptic, with almost no important adverse drug interactions [46]. It has been shown that levetiracetam does not directly affect voltage-gated sodium channels or voltage-gated T-type calcium channels [47]; although the drug exhibits a mild selective inhibition of high-voltage-gated $\mathrm{N}$-type calcium channels [48], there is no doubt that the mode of action is very different from other antiepileptics. Presumably, the main effect of levetiracetam is accomplished by binding to the vesicle transmembrane protein called SV2A and subsequently altering the regulation of calcium-dependent exocytosis of neurotransmitters into the synaptic gap [49]. Although levetiracetam is not FDA approved for monotherapy in the United States, it is used widely as a first-line treatment for focal and generalized tonic-clonic seizures and is approved for initial monotherapy in Europe. It is also an excellent adjunctive treatment owing view of its safety and absence of interactions.

Levetiracetam ( $3000 \mathrm{mg} /$ day, from 4 to 6 weeks in duration) was evaluated in 25 women with post-mastectomy pain syndrome and in 16 patients with painful polyneuropathy (Table 2). No analgesic effect was found in these studies. A higher incidence of fatigue (17.7\% and $40.0 \%)$ during levetiracetam administration was found. Only the study of Holbech 
et al. [50] compared TEAE frequencies with placebo, and no significant difference was found. In the study of Vilholm et al. [51], dizziness, headache, and gastric upset were observed in $12.0 \%$ of patients. Overall, $6.7 \%-7.7 \%$ of patients discontinued the studies because of TEAEs. According to SPC of levetiracetam, the most common TEAEs include somnolence, dizziness, and asthenia; irritability, depression, and hostility may also occur, more often in children.

3.1.2.4 Valproate. Valproic acid is an antiepileptic drug that has been shown to alter the activity of the neurotransmitter GABA by potentiating the inhibitory activity of GABA through several mechanisms, including inhibition of GABA degradation, inhibition of GABA transaminobutyratre, increased GABA synthesis, and decreased turnover [52]. Moreover, valproate attenuates $\mathrm{N}$-methyl-D-aspartate-mediated excitation [53] and blocks $\mathrm{Na}^{+}$channels, voltage-dependent L type calcium channels, and voltage-gated $\mathrm{K}^{+}$channels [54]. Valproate is normally used for the treatment of seizures, manic episodes, and bipolar disorder [55]. Valproate acid (brand name Depakote ${ }^{\circledR}$, among others) was first made in 1881 by Beverly S. Burton as an analog of valeric acid, which is found naturally in valerian. In 1962, Pierre Eymard serendipitously discovered the antiepileptic properties [56]; it was approved as an antiepileptic drug in 1967 and subsequently became the most widely prescribed antiepileptic drug worldwide [55]. Valproate acid is primarily used to treat epilepsy and bipolar disorder and to prevent migraine headaches, and it is included in the World Health Organization's List of Essential Medicines.

Valproate acid at $20 \mathrm{mg} / \mathrm{kg} / \mathrm{day}$ for 12 weeks was assessed in the presence and absence of glyceryl trinitrate spray in a randomized monocenter clinical trial in 20 patients with diabetic neuropathy versus placebo (21 patients) [57] (Table 2). In this study, a significant subjective improvement in diabetic neuropathic pain in patients receiving glyceryl 
trinitrate or sodium valproate, or both drugs in combination was observed in comparison to placebo. Both drugs, which have different mechanisms of action, appear to achieve maximum effect with minimal side effects when administered in combination. Negligible TEAEs (mainly nausea) and no dropouts were observed in groups receiving valproate either alone or in combination with glyceryl trinitrate. In this single study, the frequency of TEAEs was not compared between the study arms, and no information was available on the rate of SAEs. According to SPC of valproate, the common TEAEs include nausea, vomiting, sleepiness, and dry mouth; the SAEs are liver problems, pancreatitis, and an increased suicide risk. If taken during pregnancy, valproic acid is also known to cause serious abnormalities in the child; therefore, it is contraindicated in the case of pregnancy.

3.1.2.5 Zonisamide. Zonisamide is a sulfonamide antiepileptic drug approved in the United States, United Kingdom, Japan, and Australia for the treatment of various forms of epilepsy and Parkinson's disease [58]. Zonisamide was discovered by Uno et al. in 1972 and was first marketed by Dainippon Pharmaceutical in 1989. Zonisamide, as with several other antiepileptic drugs, prolongs the inactive phase of voltage-dependent sodium channels, thereby inhibiting the propagation of action potentials [59]. Daily doses of oral zonisamide are usually in the range of 200 to $600 \mathrm{mg}$.

Zonisamide has been used in a small number $(n=13)$ of patients with diabetic neuropathy for 12 weeks at the dose of $540 \mathrm{mg} /$ day (Table 2). The study was negative: pain scores were not statistically decreased compared with the placebo group. The tolerability of zonisamide was only fair in this study, as a high number of patients experienced at least one TEAE (91.0\%), and one patient (8.3\%) experienced the SAE of drug rash. Many TEAEs were observed, including rash, dizziness, irritation, restlessness/insomnia, and respiratory disorders. Nevertheless, the frequencies of occurrence of these TEAEs were not statistically different 
from those in the placebo group. The SPC of zonisamide describes typical TEAEs as somnolence, dizziness, and anorexia.

3.1.2.6 Ethosuximide. Ethosuximide is an FDA-approved T-type calcium-channel blocker currently used and for the management of absence seizures in patients over 3 years of age. Ethosuximide was approved for medical use in the United States in 1960, and it is on the World Health Organization's List of Essential Medicines. Numerous recent pre-clinical studies have shown its therapeutic potential for the treatment of neuropathic pain [60].

Only one proof-of-concept, multicenter, RCT has evaluated and compared the efficacy and safety of ethosuximide (administered as an add-on therapy for 6 weeks at doses from 500 to $1500 \mathrm{mg} /$ day) with the efficacy of an inactive control in 114 patients with non-diabetic neuropathic pain (Table 2). In this study, ethosuximide failed to reduce total pain after 6 weeks of treatment, compared with the inactive control. Moreover, tolerance to ethosuximide was poor in comparison to that with the inactive control, with $69.5 \%$ of patients experiencing at least one TEAEs, and a dropout rate of $59.3 \%$, mainly due to TEAEs. The most frequent TEAEs were dyspepsia (39\%), headache (32\%), and dizziness (20\%). SAEs related to ethosuximide comprised dermabrasion or self-injurious ideation/suicide attempts and were reported in four patients $(6.8 \%)$. According to the literature, the overall rate of TEAEs with ethosuximide used in epileptic patients was less than that for most other antiepileptic drugs ( $26 \%$ to $46 \%$ ); the TEAEs were mainly gastrointestinal and often diminished after 1-2 weeks. Other common TEAEs include drowsiness, lethargy, insomnia, headache, and hiccups [61]. In addition, reports exist of rare idiosyncratic reactions such as Stevens-Johnson syndrome, agranulocytosis, aplastic anemia, and systemic lupus erythematosus [62,63].

3.1.2.7 Carisbamate. Carisbamate is an investigational compound that has been shown to be 
effective and well tolerated in patients with refractory focal-onset seizures [64]. The compound may modulate neuronal excitability through the inhibition of voltage-gated sodium channels, thereby reducing action potential discharges [65]. In addition, carisbamate reduces glutamatergic transmission through the inhibition of AMPA and NMDA excitatory postsynaptic potentials [66]. Carisbamate increased the tonic activation of somatodendritic 5$\mathrm{HT}_{1 \mathrm{~A}}$ serotonergic receptors, leading to the inhibition of pyramidal neurons in the hippocampus [67]. Recent data have demonstrated that its neuroprotective and anti-seizure activity likely resulted, in part, from decreased $\left[\mathrm{Ca}^{2+}\right]_{\mathrm{i}}$ accumulation through the blockade of T-type calcium channels [68].

Carisbamate has been used in three proof-of-concept studies for its efficacy and safety in the treatment of neuropathic pain (Table 2). Studies 1 (postherpetic neuralgia) and 2 (diabetic neuropathy) followed a crossover design, in which patients received carisbamate 400 $\mathrm{mg} /$ day or placebo for 4 weeks and then the other treatment for 4 weeks. In study 3 (diabetic neuropathy), patients were randomized (1:1:1:1) to receive either carisbamate $800 \mathrm{mg} /$ day, $1200 \mathrm{mg} /$ day, pregabalin $300 \mathrm{mg} /$ day, or placebo for 15 weeks. The efficacy of carisbamate in neuropathic pain was not demonstrated in these studies. In general, carisbamate was well tolerated (from $15 \%$ to $38 \%$ of patients with at least TEAEs, according to dose), with no new or unexpected safety concerns in neuropathic pain populations compared with previous epilepsy trials $[64,69,70]$. In the current studies, only two patients in the carisbamate 800 $\mathrm{mg}$ /day group in study 3 had ALT elevations of > $3 \times \mathrm{ULN}$; in both patients, these resolved without any sequelae. TEAEs particularly relevant in the diabetic population, such as weight gain, somnolence, and peripheral edema, occurred less frequently with carisbamate than pregabalin. However, some gastrointestinal TEAEs, as well as dizziness, were more frequently reported with carisbamate than with pregabalin; however, none of these studies compared the frequency of TEAEs with placebo. According to the literature, the most 
frequently reported TEAEs associated with carisbamate are dizziness, headache, somnolence, and nausea [71].

\subsubsection{Oxcarbazepine and carbamazepine. Oxcarbazepine, a structural analog of} carbamazepine, is used to treat epilepsy. The compound was patented in 1969 and was brought into medical use in 1990. Multiple comparative monotherapy trials for new-onset focal epilepsy have demonstrated that oxcarbazepine was equal in efficacy to phenytoin and immediate-release carbamazepine with possibly superior tolerability [72,73]. Oxcarbazepine is known to cause a nonspecific sodium channel blockade [74] that may also have an effect on calcium and potassium channels $[74,75]$. Carbamazepine is also used for the treatment of neuropathic pain [76], but main trials assessing carbamazepine efficacy on peripheral neuropathic pain were published before 2000. Only one study assessing carbamazepine, in the treatment of neuropathic pain and complex regional pain syndrome I, has been included in the review but with an unclear description of adverse effects. This study concluded on positive effects of carbamazepine [77].

The efficacy and safety of oxcarbazepine has been evaluated in two multicenter double-blind, placebo-controlled, randomized clinical trials in patients with peripheral neuropathy. Oxcarbazepine was initiated at a dose of $300 \mathrm{mg} /$ day and titrated to a maximum dose of $1800 \mathrm{mg} / \mathrm{day}$ in 69 patients with diabetic neuropathy for 16 weeks in study 1 [78], and at 1800-2400 mg for two 6-week treatment periods in patients with peripheral neuropathic pain in study 2 [79]. In both studies, it was found to be efficacious for the relief of neuropathic pain. Most TEAEs were mild to moderate in severity, transient, and in line with the known tolerability profile of oxcarbazepine. The most frequent TEAEs were dizziness, somnolence, and fatigue, with diarrhea and nausea/vomiting also reported. In study 1, SAEs occurred in $10 \%$ of oxcarbazepine-treated patients. These TEAEs were considered related to 
treatment in two patients (erythema multiforme and asthenia/dizziness/fatigue). None of these studies compared the frequency of TEAEs with placebo. According to the literature, oxcarbazepine may cause drowsiness, headache, and fatigue, and higher doses may cause dizziness, blurred vision, diplopia, nausea, vomiting, and ataxia [46].

\subsection{Antidepressants}

Antidepressants form a heterogeneous group of molecules that are usually classified according to their chemical structure, psychoactive/sedative properties, and monoaminergic action; that is, by their ability to modulate serotonergic and/or noradrenergic transmission. On this basis, six classes of antidepressants can be distinguished, of which two are recommended for the treatment of peripheral or central neuropathic pain. Indeed, a systematic review and meta-analysis of published and unpublished data, including 229 RCTs, performed by the NeuPSIG, led to the recommendation of, in addition to gabapentinoids, TCAs and SNRIs as first-line treatments [11].

The efficacy of TCAs (e.g. amitriptyline, clomipramine, desipramine, imipramine, nortriptyline, protriptyline, and trimipramine) is similar regardless of the molecule used, although amitriptyline is the most commonly studied. As the number of clinical studies increases, the decrease in estimated drug efficacy, which was first observed in 2013 [11], has been recently confirmed [80]. The number needed to treat (NNT) for TCAs (amitriptyline and nortriptyline) was estimated at 3.6 in 2015; it had increased to 4-5 in 2017 [80], suggesting a decreased efficacy. In addition to the limited efficacy of these recommended treatments, the incidence of TEAEs and treatment interruption due to TEAEs may also contribute to the unsatisfactory management of neuropathic pain. Indeed, in addition to serotonin and noradrenaline, TCAs can interfere with other neurotransmitters, causing many adverse effects. 
SNRIs (e.g. duloxetine, venlafaxine, and milnacipran) appear to be more selective than TCAs and cause fewer TEAEs: the efficacy of the SNRIs venlafaxine and duloxetine has been shown with an overall estimated NNT of 6.4 and an NNH of 11.8 [11]. TEAEs include digestive disorders (nausea, abdominal pain, and constipation), dizziness, somnolence, and a risk of high blood pressure. The risk of serotonin syndrome contraindicates the association with monoamine oxidase inhibitors, and the use of other molecules capable of interfering with serotonin is a precautionary measure (especially the association with tramadol). Although TCAs and SNRIs have a moderate and significant level of evidence, respectively, the selective serotonin reuptake inhibitors (SSRIs) (e.g., citalopram, escitalopram, fluoxetine, fluvoxamine, paroxetine, and sertraline) have an inconclusive level of evidence.

In the present review, we identified 24 double-blind, placebo-controlled, randomized clinical trials that examined the TEAEs related to antidepressants strongly recommended for use in neuropathic pain. The trials included 3998 patients; 15 were of SNRIs (9 with duloxetine, 5 with venlafaxine, and 1 with milnacipran) and 8 were of TCAs (6 with amitriptyline, 1 with nortriptyline, and 1 with imipramine). One publication presented results on escitalopram efficacy on various neuropathic pain conditions.

\subsubsection{Serotonin and noradrenaline reuptake inhibitors (SNRIs)}

3.2.1.1 Duloxetine. Duloxetine (Cymbalta $\left.{ }^{\circledR}\right)$ was created by researchers at Eli Lilly in the 1990s [81], approved in United States in 2004, and is indicated for the treatment of major depressive disorder, generalized anxiety disorder, diabetic neuropathic pain, fibromyalgia, and chronic musculoskeletal pain. Duloxetine inhibits the reuptake of serotonin and noradrenaline in the central nervous system, and increases dopamine specifically in the prefrontal cortex, via the inhibition of the noradrenaline reuptake transporter, which is believed to mediate reuptake of dopamine and noradrenaline [82]. The analgesic action of duloxetine in the treatment of 
diabetic neuropathic pain and central pain syndromes are due to $\mathrm{Na}^{+}$ion channel inhibition [83].

In total, 3173 patients were included in the 9 RCTs; 2126 received duloxetine at daily dose from $20 \mathrm{mg}$ to $120 \mathrm{mg}$ for a treatment duration from 4 weeks to 12 weeks. The majority of studies showed positive results (7/9). Except for patient groups treated with $20 \mathrm{or} 40 \mathrm{mg}$ daily, the most common TEAEs, i.e., TEAEs that occurred significantly more frequently in the duloxetine (60 or $120 \mathrm{mg} /$ day) group than in the placebo group, were nausea $(10.4 \%-$ $32.1 \%)$, constipation/diarrhea (10.6\%-19.0\%), somnolence $(15.0 \%-28.3 \%)$, and dizziness $(11.0 \%-23.0 \%)$. Only three studies reported dry mouth $(10 \%-35 \%)$, two reported decreased appetite $(12.4 \%-19.0 \%)$, and one study reported hyperhidrosis $(10.0 \%)$ in patients receiving duloxetine $120 \mathrm{mg}$ daily. The occurrence of dropouts due to TEAEs was from $4.3 \%$ to $19.4 \%$ whatever the dose. SAEs occurred in $0.0 \%$ to $6.7 \%$ of patients treated with duloxetine.

\subsubsection{Venlafaxine. The SNRI venlafaxine hydrochloride (Effexor $\left.{ }^{\circledR}\right)$, first introduced by} Wyeth in 1993, is indicated for the treatment of major depressive disorder and social anxiety disorder. Preclinical studies have shown that venlafaxine and its active metabolite, Odesmethylvenlafaxine, are potent inhibitors of neuronal serotonin and noradrenaline reuptake, and weak inhibitors of dopamine reuptake. Venlafaxine and O-desmethylvenlafaxine have no significant affinity for muscarinic cholinergic, H1-histaminergic, or $\alpha 1$-adrenergic receptors in vitro. Pharmacologic activity at these receptors is hypothesized to be associated with the various anticholinergic, sedative, and cardiovascular effects seen with other psychotropic drugs. Venlafaxine and O-desmethylvenlafaxine do not possess monoamine oxidase (MAO) inhibitory activity $[84,85]$.

We identified five RCTs of venlafaxine with a 37.5-150 mg daily dose and a treatment duration from 11 days to 56 days. The etiology of neuropathic pain was various neuropathies. 
Among these five studies, only one was positive, and TEAEs were reported in only two studies. The most frequent TEAEs were asthenia/fatigue, sweating, and dry mouth, followed by headache, constipation, and nausea. No significant SAEs related to venlafaxine treatment were reported. The dropout rate due to TEAEs, reported in four of the five studies, was 9/98 $(9.2 \%)$ treated patients.

3.2.1.3 Milnacipran. Milnacipran hydrochloride (Savella®) is a selective serotonin and noradrenaline dual reuptake inhibitor. Originally developed and manufactured by Pierre Fabre Medicament, it was approved in France in 1997 as an antidepressant and by the FDA in 2009 for the management of fibromyalgia [86]. Only one study, with a 10-week duration, reported the use of milnacipran in neuropathic pain due to radiculopathy. The small number of patients $(n=7)$ did not permit the evaluation of the significance of TEAEs; however, $28.7 \%$ of patients discontinued the study due to TEAEs.

\subsubsection{Tricyclic antidepressants (TCAs)}

Among TCAs, amitriptyline is the most studied. Amitriptyline (sold under the trade name Elavil@) was discovered in 1960 and approved by the FDA in 1961 [87]. It is on the World Health Organization's List of Essential Medicines. Amitriptyline inhibits the neuronal reuptake of serotonin and noradrenaline from synapses in the central nervous system, with strong activity on the serotonin transporter and moderate activity on the norepinephrine transporter [88]. Amitriptyline also modulates several receptors and ion channels, such as the serotonin, $\alpha 1$-adrenergic, H1, H2, muscarinic acetylcholine, sigma-1, NMDA, TrkA, and TrkB receptors, and sodium, L-type calcium, and voltage-gated potassium channels [89-94].

In the present review, we identified eight double-blind, placebo-controlled, randomized clinical trials, six evaluated amitriptyline, one evaluated nortriptyline, and one 
evaluating imipramine in various neuropathic pain conditions. One study lasted 12 weeks; the rest were short-controlled studies, lasting between 1 and 5 weeks. TCAs were administered systemically for all studies, with the exception of two controlled trials using topical amitriptyline ( $2 \%$ or $5 \%$ gel). Only the study investigating imipramine had positive results. TEAEs, e.g. dry mouth, dizziness, and constipation, were reported only in patients receiving nortriptyline $100 \mathrm{mg}$ daily for 4 weeks. Dropout due to TEAEs occurred in $17 \%$ and $3.9 \%$ of patients treated with imipramine and nortriptyline, respectively. Amitriptyline led to dropout rates of $10 \%$ in one trial (over four p.o. routes) and $4.5 \%$ in another trial (over two topical routes).

\subsubsection{Escitalopram}

Escitalopram, a pharmacologically active S-(+)-enantiomer of citalopram, potentiates serotonergic neurotransmission in the central nervous system through selectively binding to the serotonin transporter to inhibit 5-HT reuptake [95]. Escitalopram is mainly indicated in depressive disorders [95]. Indeed, escitalopram, as for other SSRIs, is not recommended for the management of neuropathic pain [11].

Escitalopram (10-20 mg/day for 6 weeks) has been assessed in only one crossover RCT, which included 48 patients with various types of neuropathic pain (Table 3). A clinically relevant efficacy of escitalopram was found for a very small number of patients. However, $51.2 \%$ of patients experienced TEAEs, the most frequent of which were digestive disorders (abdominal discomfort and nausea/vomiting), and $10.4 \%$ of patients discontinued the study because of TEAEs.

\section{Conclusion}

Among the selected studies, when a statistical analysis of TEAEs was performed in 
comparison to the placebo groups, the rate of any TEAEs ranged from $7.0 \%$ to $91.7 \%$, and the highest rate was found for duloxetine $(46.5 \%-89.5 \%, \mathrm{p}<0.05)$. The most frequently cited TEAEs in the included studies with a statistical analysis were nausea (all 10.4\%-43.1\%, p < 0.05; duloxetine 10.4\%-32.1\% and venlafaxine 43.1\%), drowsiness (all 15.0\%-28.3\%, p < 0.05; duloxetine 15.0\%-28.3\% and gabapentin, 27.8\%), dizziness (all 11.0\%-49.0\%, $\mathrm{p}<$ 0.05; duloxetine 11.0\%-23.0\%; pregabalin 13.7\%; gabapentin 37.3\%; and nortriptyline 49.0\%), constipation (all 10.6\%-41.0\%, p < 0.05; duloxetine 10.6\%-18.8\%; and nortriptyline, $41 \%$ ), fatigue (duloxetine $11.0 \%-12.5 \%, \mathrm{p}<0.05$ ), headache (all 10.5\%-25.0\%, $\mathrm{p}>0.05$ ), and dry mouth (all 10.0\%-62.0\%, p < 0.05; duloxetine 10.0\%-35.0\%; and nortriptyline $62.0 \%)$

Gabapentin and pregabalin have similar safety profiles, with the same types and frequencies of occurrence of TEAEs. In terms of efficacy, pregabalin appeared to be more effective for the treatment of neuropathic pain than gabapentin. The small number of studies and types of peripheral neuropathy evaluated did not allow conclusions to be drawn on the safety of mirogabalin. The first studies appeared promising, with a better efficacy (one study demonstrated a better efficacy than pregabalin) and fewer TEAEs than pregabalin and gabapentin. However, a recent article [39], including three clinical trials, showed that the frequency of TEAEs related to mirogabalin $(74.8 \%)$ was similar to pregabalin, including dizziness $(15.2 \%)$, headache (13.5\%), and drowsiness (9.6\%). Unfortunately, the frequency of occurrence was not compared with the placebo group, and the authors concluded that mirogabalin was ineffective for the treatment of pain related to fibromyalgia. Finally, owing to the limited analgesic efficacy and the high frequency of TEAEs (over $50 \%$ of patients for gabapentin and pregabalin), the safety of gabapentinoids for the treatment of neuropathic pain was far from optimal, especially when the risks of addiction and misuse induced by these molecules were accounted for [25]. For other antiepileptics, the small number of studies with 
a good assessment of TEAEs made it difficult to draw conclusions on their safety.

Nevertheless, the occurrence of TEAEs, ranging from $56.0 \%$ to $94.0 \%$, and the relatively low proportion of positive studies (9/17) may suggest concerns regarding the safety for other antiepileptics. It should also be noted that carisbamate appear to stand out, with a TEAE occurrence between $15 \%$ and $38 \%$ according to the dose and proven efficacy, but this should be taken with caution, as only one study was reviewed.

With respect to antidepressants, the majority of studies (9/24) evaluated duloxetine, making it difficult to conclude on the safety of other antidepressants owing to the small number of studies. Studies on duloxetine have shown moderate tolerance, but this was counterbalanced by a high analgesic efficacy ( 7 positive studies out of 9$)$. Indeed, the therapeutic effects were more modest, or even absent, with only one positive study out of the five studies of venlafaxine and no positive studies for amitriptyline. As each of the other molecules have been evaluated only in a single study, we could not conclude on their safety. It should be noted that in these studies, only milnacipran and imipramine were demonstrated as effective.

\section{Expert opinion}

Overall, duloxetine appeared to have the most detailed safety for the treatment of neuropathic pain compared with other antidepressants and with antiepileptics. For all studies, the most commonly reported adverse effects were dizziness, drowsiness, nausea, and constipation. The great majority of these TEAEs were not life-threatening, although TEAEs such as dizziness and drowsiness alter the quality of life of patients [96,97]. These TEAEs may be a contributory factor to the low adherence rate and the under use of pain medications $[98,99]$. Patients with chronic pain had a low adherence rate to pain medications (e.g., $40 \%$ for various types of chronic pain [99], 50\%-91\% for cancer pain, and 63\% for rheumatoid arthritis 
[100]). As antidepressants and antiepileptics used in the treatment of peripheral neuropathic pain have equivocal efficacy and safety concerns, the assessment of the benefit-risk ratio would be particularly relevant.

The main weakness of this review is related to the fact that many clinical trials included in this review had a poor description of the safety of the assessed drugs. Although double-blind, placebo-controlled, randomized clinical trials have been included in this review, only $20.0 \%$ (18) of studies presented statistical comparisons of TEAEs between groups: $62.2 \%$ (56) did not present any statistical comparisons and $17.8 \%$ (16) provided insufficient details on TEAE frequencies or no safety data. Only $43.8 \%$ (39) of studies reported SAEs and $84.3 \%$ (75) reported dropout of patients owing to TEAEs. Consequently, caution must be taken when assessing the frequency of TEAEs in these studies. Frequently, authors did not mention if the observed adverse events were related to the assessed medications, which may have contributed to an overestimation of reported TEAEs in this review. Many issues have been raised regarding the assessment and reporting of drug safety during RCTs [101]; however, no evidentiary gold standard for safety assessment has been defined. RCTs have a limited statistical power for TEAE assessment as sample sizes are designed for the main objective of efficacy. In addition, the lack of adequate ascertainment and classification of TEAEs leads to inconsistencies in the reporting of TEAEs. The hyper-selection of patients through restrictive inclusion and exclusion criteria leads to limited generalizability [101]. We encourage the publication of clinical trials in accordance with CONSORT guidelines [102]; furthermore, authors should incorporate in their manuscript a table describing all the observed adverse events, including the relationship between the adverse events and treatments, serious TEAEs, the dropout rate related to TEAEs, and the statistical significance of these TEAEs versus a placebo. 
The management of peripheral neuropathic pain is a largely unmet medical need [11].

Pain physicians and patients are still waiting for pharmacological innovations that will improve the safety of pain medications.

\section{Article highlights box}

- Review of double-blind, placebo-controlled, randomized clinical trials

- Specific focus on adverse effects of antidepressant and antiepileptic medications used to treat peripheral neuropathic pain

- Duloxetine presents the most detailed safety for the treatment of peripheral neuropathic pain

- Adverse drug reactions are under-reported in most of the clinical trials

- A detailed safety assessment of antidepressant and antiepileptic medications should be mandatory for clinical trials on peripheral neuropathic pain 


\section{References}

[1] Finnerup NB, Haroutounian S, Kamerman P, et al. Neuropathic pain: an updated grading system for research and clinical practice. Pain. 2016;157:1599-1606.

•: Grading and definition of neuropathic pain

[2] Martyn CN, Hughes RA. Epidemiology of peripheral neuropathy. J. Neurol. Neurosurg. Psychiatry. 1997;62:310-318.

[3] Zis P, Sarrigiannis PG, Rao DG, et al. Chronic idiopathic axonal polyneuropathy: a systematic review. J. Neurol. 2016;263:1903-1910.

[4] Katona I, Weis J. Diseases of the peripheral nerves. Handb Clin Neurol. 2017;145:453474.

[5] Chenaf C, Delorme J, Delage N, et al. Prevalence of chronic pain with or without neuropathic characteristics in France using the capture-recapture method: a populationbased study. Pain. 2018;159:2394-2402.

-: French actual data on the prevalence of neuropathic pain

[6] DiBonaventura MD, Sadosky A, Concialdi K, et al. The prevalence of probable neuropathic pain in the US: results from a multimodal general-population health survey. J Pain Res. 2017;10:2525-2538.

[7] van Hecke O, Austin SK, Khan RA, et al. Neuropathic pain in the general population: a systematic review of epidemiological studies. Pain. 2014;155:654-662.

[8] Scholz J, Finnerup NB, Attal N, et al. The IASP classification of chronic pain for ICD11: chronic neuropathic pain. Pain. 2019;160:53-59.

[9] Abbott CA, Malik RA, van Ross ERE, et al. Prevalence and characteristics of painful diabetic neuropathy in a large community-based diabetic population in the U.K. Diabetes Care. 2011;34:2220-2224.

[10] de Carvalho Barbosa M, Kosturakis AK, Eng C, et al. A quantitative sensory analysis of peripheral neuropathy in colorectal cancer and its exacerbation by oxaliplatin chemotherapy. Cancer Res. 2014;74:5955-5962.

[11] Finnerup NB, Attal N, Haroutounian S, et al. Pharmacotherapy for neuropathic pain in adults: a systematic review and meta-analysis. Lancet Neurol. 2015;14:162-173.

••: Current guidelines for the management of neuropathic pain 
[12] Hershman DL, Lacchetti C, Dworkin RH, et al. Prevention and management of chemotherapy-induced peripheral neuropathy in survivors of adult cancers: American Society of Clinical Oncology clinical practice guideline. J. Clin. Oncol. 2014;32:19411967.

$\bullet \bullet:$ Current guidelines for the management of CIPN

[13] Perucca P, Gilliam FG. Adverse effects of antiepileptic drugs. Lancet Neurol. 2012;11:792-802.

[14] Mevaag M, Henning O, Baftiu A, et al. Discrepancies between physicians' prescriptions and patients' use of antiepileptic drugs. Acta Neurologica Scandinavica. 2017;135:8087.

[15] Gilliam FG, Fessler AJ, Baker G, et al. Systematic screening allows reduction of adverse antiepileptic drug effects: a randomized trial. Neurology. 2004;62:23-27.

[16] Calandre EP, Rico-Villademoros F, Slim M. Alpha2delta ligands, gabapentin, pregabalin and mirogabalin: a review of their clinical pharmacology and therapeutic use. Expert Rev Neurother. 2016;16:1263-1277.

[17] Gabapentin Monograph for Professionals - Drugs.com [Internet]. 2017 [cited 2019 Nov 29]. Available from: https://web.archive.org/web/20170819150204/https://www.drugs.com/monograph/gaba pentin.html.

[18] Landefeld CS, Steinman MA. The Neurontin legacy--marketing through misinformation and manipulation. N. Engl. J. Med. 2009;360:103-106.

[19] Sills GJ. The mechanisms of action of gabapentin and pregabalin. Curr Opin Pharmacol. 2006;6:108-113.

[20] The Top 300 of 2019 [Internet]. [cited 2019 Nov 29]. Available from: https://clincalc.com/DrugStats/Top300Drugs.aspx.

[21] Attal N, Cruccu G, Baron R, et al. EFNS guidelines on the pharmacological treatment of neuropathic pain: 2010 revision. Eur. J. Neurol. 2010;17:1113-e88.

[22] Wiffen PJ, Derry S, Bell RF, et al. Gabapentin for chronic neuropathic pain in adults. Cochrane Database Syst Rev. 2017;6:CD007938.

[23] Mersfelder TL, Nichols WH. Gabapentin: Abuse, Dependence, and Withdrawal. Ann Pharmacother. 2016;50:229-233.

[24] Smith RV, Havens JR, Walsh SL. Gabapentin misuse, abuse and diversion: a systematic review. Addiction. 2016;111:1160-1174.

[25] Evoy KE, Covvey JR, Peckham AM, et al. Reports of gabapentin and pregabalin abuse, misuse, dependence, or overdose: An analysis of the Food And Drug Administration Adverse Events Reporting System (FAERS). Res Social Adm Pharm. 2019;15:953-958. 
[26] Frampton JE. Pregabalin: a review of its use in adults with generalized anxiety disorder. CNS Drugs. 2014;28:835-854.

[27] Iftikhar IH, Alghothani L, Trotti LM. Gabapentin enacarbil, pregabalin and rotigotine are equally effective in restless legs syndrome: a comparative meta-analysis. Eur. J. Neurol. 2017;24:1446-1456.

[28] Baidya DK, Agarwal A, Khanna P, et al. Pregabalin in acute and chronic pain. J Anaesthesiol Clin Pharmacol. 2011;27:307-314.

[29] Bryans JS, Wustrow DJ. 3-substituted GABA analogs with central nervous system activity: a review. Med Res Rev. 1999;19:149-177.

[30] Lauria-Horner BA, Pohl RB. Pregabalin: a new anxiolytic. Expert Opin Investig Drugs. 2003;12:663-672.

[31] Enke O, New HA, New CH, et al. Anticonvulsants in the treatment of low back pain and lumbar radicular pain: a systematic review and meta-analysis. CMAJ. 2018;190:E786E793.

[32] Shanthanna H, Gilron I, Rajarathinam M, et al. Benefits and safety of gabapentinoids in chronic low back pain: A systematic review and meta-analysis of randomized controlled trials. PLoS Med. 2017;14:e1002369.

[33] Bennett MI, Laird B, van Litsenburg C, et al. Pregabalin for the management of neuropathic pain in adults with cancer: a systematic review of the literature. Pain Med. 2013;14:1681-1688.

[34] Linde M, Mulleners WM, Chronicle EP, et al. Gabapentin or pregabalin for the prophylaxis of episodic migraine in adults. Cochrane Database Syst Rev. 2013;CD010609.

[35] Clarke H, Bonin RP, Orser BA, et al. The prevention of chronic postsurgical pain using gabapentin and pregabalin: a combined systematic review and meta-analysis. Anesth. Analg. 2012;115:428-442.

[36] Chaparro LE, Smith SA, Moore RA, et al. Pharmacotherapy for the prevention of chronic pain after surgery in adults. Cochrane Database Syst Rev. 2013;CD008307.

[37] Derry S, Bell RF, Straube S, et al. Pregabalin for neuropathic pain in adults. Cochrane Database Syst Rev. 2019;1:CD007076.

[38] Simpson DM, Rice ASC, Emir B, et al. A randomized, double-blind, placebo-controlled trial and open-label extension study to evaluate the efficacy and safety of pregabalin in the treatment of neuropathic pain associated with human immunodeficiency virus neuropathy. Pain. 2014;155:1943-1954.

[39] Arnold LM, Whitaker S, Hsu C, et al. Efficacy and safety of mirogabalin for the treatment of fibromyalgia: results from three 13-week randomized, double-blind, placebo- and active-controlled, parallel-group studies and a 52-week open-label extension study. Current Medical Research and Opinion. 2019;35:1825-1835. 
[40] Merante D, Rosenstock J, Sharma U, et al. Efficacy of Mirogabalin (DS-5565) on Patient-Reported Pain and Sleep Interference in Patients with Diabetic Neuropathic Pain: Secondary Outcomes of a Phase II Proof-of-Concept Study. Pain Med. 2017;18:21982207.

[41] Mendell J, Levy-Cooperman N, Sellers E, et al. Abuse potential of mirogabalin in recreational polydrug users. Ther Adv Drug Saf. 2019;10:2042098619836032.

[42] Cheung H, Kamp D, Harris E. An in vitro investigation of the action of lamotrigine on neuronal voltage-activated sodium channels. Epilepsy Res. 1992;13:107-112.

[43] Dibué-Adjei M, Kamp MA, Alpdogan S, et al. Cav2.3 (R-Type) Calcium Channels are Critical for Mediating Anticonvulsive and Neuroprotective Properties of Lamotrigine In Vivo. Cell. Physiol. Biochem. 2017;44:935-947.

[44] Silver M, Blum D, Grainger J, et al. Double-blind, placebo-controlled trial of lamotrigine in combination with other medications for neuropathic pain. J Pain Symptom Manage. 2007;34:446-454.

[45] Choi D, Stables JP, Kohn H. Synthesis and anticonvulsant activities of N-Benzyl-2acetamidopropionamide derivatives. J. Med. Chem. 1996;39:1907-1916.

[46] Abou-Khalil BW. Update on Antiepileptic Drugs 2019. Continuum (Minneap Minn). 2019;25:508-536.

[47] Zona C, Niespodziany I, Marchetti C, et al. Levetiracetam does not modulate neuronal voltage-gated $\mathrm{Na}+$ and T-type Ca2+ currents. Seizure. 2001;10:279-286.

[48] Lukyanetz EA, Shkryl VM, Kostyuk PG. Selective blockade of N-type calcium channels by levetiracetam. Epilepsia. 2002;43:9-18.

[49] Lynch BA, Lambeng N, Nocka K, et al. The synaptic vesicle protein SV2A is the binding site for the antiepileptic drug levetiracetam. Proc. Natl. Acad. Sci. U.S.A. 2004;101:9861-9866.

[50] Holbech JV, Otto M, Bach FW, et al. The anticonvulsant levetiracetam for the treatment of pain in polyneuropathy: a randomized, placebo-controlled, cross-over trial. Eur J Pain. 2011;15:608-614.

[51] Vilholm OJ, Cold S, Rasmussen L, et al. Effect of levetiracetam on the postmastectomy pain syndrome. Eur. J. Neurol. 2008;15:851-857.

[52] Mesdjian E, Ciesielski L, Valli M, et al. Sodium valproate: kinetic profile and effects on GABA levels in various brain areas of the rat. Prog. Neuropsychopharmacol. Biol. Psychiatry. 1982;6:223-233.

[53] Gean P-W, Huang C-C, Hung C-R, et al. Valproic acid suppresses the synaptic response mediated by the NMDA receptors in rat amygdalar slices. Brain Research Bulletin. 1994;33:333-336.

[54] VanDongen AMJ, VanErp MG, Voskuyl RA. Valproate Reduces Excitability by Blockage of Sodium and Potassium Conductance. Epilepsia. 1986;27:177-182. 
[55] Perucca E. Pharmacological and therapeutic properties of valproate: a summary after 35 years of clinical experience. CNS Drugs. 2002;16:695-714.

[56] Meunier H, Carraz G, Neunier Y, et al. [Pharmacodynamic properties of Ndipropylacetic acid]. Therapie. 1963;18:435-438.

[57] Agrawal RP, Goswami J, Jain S, et al. Management of diabetic neuropathy by sodium valproate and glyceryl trinitrate spray: a prospective double-blind randomized placebocontrolled study. Diabetes Res. Clin. Pract. 2009;83:371-378.

[58] Grover ND, Limaye RP, Gokhale DV, et al. Zonisamide: a review of the clinical and experimental evidence for its use in Parkinson's disease. Indian J Pharmacol. 2013;45:547-555.

[59] Schauf CL. Zonisamide enhances slow sodium inactivation in Myxicola. Brain Res. 1987;413:185-188.

[60] Bourinet E, Francois A, Laffray S. T-type calcium channels in neuropathic pain. Pain. 2016;157 Suppl 1:S15-22.

[61] Hanrahan B, Carson RP. Ethosuximide. StatPearls [Internet]. Treasure Island (FL): StatPearls Publishing; 2019 [cited 2019 Dec 11]. Available from: http://www.ncbi.nlm.nih.gov/books/NBK544244/.

[62] van Wieringen A, Vrijlandt CM. Ethosuximide intoxication caused by interaction with isoniazid. Neurology. 1983;33:1227-1227.

[63] Kuhnz W, Koch S, Jakob S, et al. Ethosuximide in epileptic women during pregnancy and lactation period. Placental transfer, serum concentrations in nursed infants and clinical status. Br J Clin Pharmacol. 1984;18:671-677.

[64] Faught E, Holmes GL, Rosenfeld WE, et al. Randomized, controlled, dose-ranging trial of carisbamate for partial-onset seizures. Neurology. 2008;71:1586-1593.

[65] Liu Y, Yohrling GJ, Wang Y, et al. Carisbamate, a novel neuromodulator, inhibits voltage-gated sodium channels and action potential firing of rat hippocampal neurons. Epilepsy Res. 2009;83:66-72.

[66] Lee C-Y, Lee M-L, Shih C-C, et al. Carisbamate (RWJ-333369) inhibits glutamate transmission in the granule cell of the dentate gyrus. Neuropharmacology. 2011;61:1239-1247.

[67] Shim S, El Mansari M, Blier P. Modulation of the Antidepressant-Like Effects of Sustained Administration of Carisbamate and Lamotrigine on Monoaminergic Systems: Electrophysiological Studies in the Rat Brain. Journal of Pharmacology and Experimental Therapeutics. 2013;347:487-496.

[68] Kim DY, Zhang F-X, Nakanishi ST, et al. Carisbamate blockade of T-type voltage-gated calcium channels. Epilepsia. 2017;58:617-626.

[69] Halford JJ, Ben-Menachem E, Kwan P, et al. A randomized, double-blind, placebocontrolled study of the efficacy, safety, and tolerability of adjunctive carisbamate 
treatment in patients with partial-onset seizures: Adjunctive Carisbamate Treatment for POS. Epilepsia. 2011;52:816-825.

[70] Sperling MR, Greenspan A, Cramer JA, et al. Carisbamate as adjunctive treatment of partial onset seizures in adults in two randomized, placebo-controlled trials. Epilepsia. 2010;51:333-343.

[71] Kulig K, Malawska B. Carisbamate, a new carbamate for the treatment of epilepsy. IDrugs. 2007;10:720-727.

[72] Nolan SJ, Muller M, Tudur Smith C, et al. Oxcarbazepine versus phenytoin monotherapy for epilepsy. Cochrane Database Syst Rev. 2013;CD003615.

[73] Koch MW, Polman SK. Oxcarbazepine versus carbamazepine monotherapy for partial onset seizures. Cochrane Database Syst Rev. 2009;CD006453.

[74] McLean MJ, Schmutz M, Wamil AW, et al. Oxcarbazepine: mechanisms of action. Epilepsia. 1994;35 Suppl 3:S5-9.

[75] Stefani A, Pisani A, De Murtas M, et al. Action of GP 47779, the active metabolite of oxcarbazepine, on the corticostriatal system. II. Modulation of high-voltage-activated calcium currents. Epilepsia. 1995;36:997-1002.

[76] Wiffen PJ, Derry S, Moore RA, et al. Carbamazepine for chronic neuropathic pain and fibromyalgia in adults. Cochrane Database Syst Rev. 2014;CD005451.

[77] Harke H, Gretenkort P, Ladleif HU, et al. The response of neuropathic pain and pain in complex regional pain syndrome I to carbamazepine and sustained-release morphine in patients pretreated with spinal cord stimulation: a double-blinded randomized study. Anesth. Analg. 2001;92:488-495.

[78] Dogra S, Beydoun S, Mazzola J, et al. Oxcarbazepine in painful diabetic neuropathy: a randomized, placebo-controlled study. Eur J Pain. 2005;9:543-554.

[79] Demant DT, Lund K, Vollert J, et al. The effect of oxcarbazepine in peripheral neuropathic pain depends on pain phenotype: a randomised, double-blind, placebocontrolled phenotype-stratified study. Pain. 2014;155:2263-2273.

[80] Finnerup NB, Haroutounian S, Baron R, et al. Neuropathic pain clinical trials: factors associated with decreases in estimated drug efficacy. Pain. 2018;159:2339-2346.

[81] Bymaster FP, Beedle EE, Findlay J, et al. Duloxetine (Cymbalta), a dual inhibitor of serotonin and norepinephrine reuptake. Bioorg. Med. Chem. Lett. 2003;13:4477-4480.

[82] Bymaster FP, Lee TC, Knadler MP, et al. The dual transporter inhibitor duloxetine: a review of its preclinical pharmacology, pharmacokinetic profile, and clinical results in depression. Curr. Pharm. Des. 2005;11:1475-1493.

[83] Wang S-Y, Calderon J, Kuo Wang G. Block of neuronal Na+ channels by antidepressant duloxetine in a state-dependent manner. Anesthesiology. 2010;113:655-665. 
[84] Food and Drug Administration. FDA approved labeling for NDA 20-699/S-022 [Internet]. Food and Drug Administration; 2003 [cited 2019 Jan 2]. Available from: https://www.accessdata.fda.gov/drugsatfda_docs/label/2003/020699s022lbl.pdf.

[85] Muth EA, Haskins JT, Moyer JA, et al. Antidepressant biochemical profile of the novel bicyclic compound Wy-45,030, an ethyl cyclohexanol derivative. Biochem. Pharmacol. 1986;35:4493-4497.

[86] Rappaport BA. NDA 22-256 Savella Addendum to Division Director Review and Summary Basis for Approval Recommendation [Internet]. Food and Drug Administration; 2009 [cited 2019 Jan 2]. Available from: https://www.accessdata.fda.gov/drugsatfda_docs/summary_review/2009/022256s000S umR.pdf.

[87] Fangmann P, Assion H-J, Juckel G, et al. Half a century of antidepressant drugs: on the clinical introduction of monoamine oxidase inhibitors, tricyclics, and tetracyclics. Part II: tricyclics and tetracyclics. J Clin Psychopharmacol. 2008;28:1-4.

[88] Tatsumi M, Groshan K, Blakely RD, et al. Pharmacological profile of antidepressants and related compounds at human monoamine transporters. Eur. J. Pharmacol. 1997;340:249-258.

[89] Owens MJ, Morgan WN, Plott SJ, et al. Neurotransmitter receptor and transporter binding profile of antidepressants and their metabolites. J. Pharmacol. Exp. Ther. 1997;283:1305-1322.

[90] Rauser L, Savage JE, Meltzer HY, et al. Inverse agonist actions of typical and atypical antipsychotic drugs at the human 5-hydroxytryptamine(2C) receptor. J. Pharmacol. Exp. Ther. 2001;299:83-89.

[91] Sills MA, Loo PS. Tricyclic antidepressants and dextromethorphan bind with higher affinity to the phencyclidine receptor in the absence of magnesium and L-glutamate. Mol. Pharmacol. 1989;36:160-165.

[92] Pancrazio JJ, Kamatchi GL, Roscoe AK, et al. Inhibition of neuronal Na+ channels by antidepressant drugs. J. Pharmacol. Exp. Ther. 1998;284:208-214.

[93] Punke MA, Friederich P. Amitriptyline is a potent blocker of human Kv1.1 and Kv7.2/7.3 channels. Anesth. Analg. 2007;104:1256-1264, tables of contents.

[94] Jang S-W, Liu X, Chan C-B, et al. Amitriptyline is a TrkA and TrkB receptor agonist that promotes TrkA/TrkB heterodimerization and has potent neurotrophic activity. Chem. Biol. 2009;16:644-656.

[95] Pastoor D, Gobburu J. Clinical pharmacology review of escitalopram for the treatment of depression. Expert Opin Drug Metab Toxicol. 2014;10:121-128.

[96] Van Gastel A. Drug-Induced Insomnia and Excessive Sleepiness. Sleep Medicine Clinics. 2018;13:147-159.

[97] Shoair OA, Nyandege AN, Slattum PW. Medication-Related Dizziness in the Older Adult. Otolaryngologic Clinics of North America. 2011;44:455-471. 
[98] Oladapo AO, Barner JC, Rascati KL, et al. A Retrospective Database Analysis of Neuropathic Pain and Oral Antidiabetic Medication Use and Adherence Among Texas Adults With Type 2 Diabetes Enrolled in Medicaid. Clinical Therapeutics. 2012;34:605613.

[99] Timmerman L, Stronks DL, Groeneweg JG, et al. Prevalence and determinants of medication non-adherence in chronic pain patients: a systematic review. Acta Anaesthesiol. Scand. 2016;60:416-431.

[100] Butow P, Sharpe L. The impact of communication on adherence in pain management. Pain. 2013;154 Suppl 1:S101-107.

[101] Singh S, Loke YK. Drug safety assessment in clinical trials: methodological challenges and opportunities. Trials. 2012;13:138.

-: Methodological discussion about the assessment of drug safety

[102] Schulz KF, Altman DG, Moher D, et al. CONSORT 2010 statement: updated guidelines for reporting parallel group randomised trials. BMJ. 2010;340:c332.

••: Current guidelines for double-blind, placebo-controlled, randomized clinical trials 
Figure 1: Flow diagram of publication selection 


\begin{tabular}{|c|c|c|c|c|c|c|c|c|}
\hline Authors' names & Study design & $\begin{array}{l}\text { Drug/comparator and dose } \\
\text { (patient number) }\end{array}$ & Duration & Pathology & $\begin{array}{l}\text { List of TEAEs in study drug } \\
\text { arm } \\
\text { ( } \geq 10 \% \text { of patients) }\end{array}$ & $\begin{array}{l}\text { SAEs related to } \\
\text { study drug }(\%)\end{array}$ & $\begin{array}{l}\text { Dropout due to } \\
\text { TEAE in study } \\
\text { drug } \operatorname{arm}(\%)\end{array}$ & $\begin{array}{l}\text { Reference } \\
\text { (PMID) }\end{array}$ \\
\hline \multicolumn{9}{|l|}{ Pregabalin } \\
\hline $\begin{array}{l}\text { Reyad et al. } \\
2019\end{array}$ & $\begin{array}{l}\text { Parallel-group } \\
\text { Monocenter }\end{array}$ & $\begin{array}{l}\text { Pregabalin 75-300 mg/day (100) } \\
\text { Placebo (100) }\end{array}$ & 7 days & $\begin{array}{l}\text { Post-traumatic neuropathic } \\
\text { pain }\end{array}$ & $\begin{array}{l}\text { Any }(7.0) \text { ns } \\
\text { No TEAE } \geq 10 \% \text { of patients }\end{array}$ & UK & UK & 30359684 \\
\hline $\begin{array}{l}\text { Jiang et al. } \\
2019\end{array}$ & $\begin{array}{l}\text { Parallel-group } \\
\text { Multicenter }\end{array}$ & $\begin{array}{l}\text { Pregabalin 75-150 mg/day (68) } \\
\text { Placebo (69) }\end{array}$ & 16 weeks & $\begin{array}{l}\text { Radiotherapy-Related } \\
\text { Neuropathic Pain }\end{array}$ & $\begin{array}{l}\text { Any (54.7) ns } \\
\text { Dizziness (18.8) \# } \\
\text { Drowsiness (20.3) \# }\end{array}$ & UK & 1.5 & 30457920 \\
\hline $\begin{array}{l}\text { Mu et al. } \\
2018\end{array}$ & $\begin{array}{l}\text { Parallel-group } \\
\text { Multicenter }\end{array}$ & $\begin{array}{l}\text { Pregabalin 150-300 mg/day (314) } \\
\text { Placebo (309) }\end{array}$ & 11 weeks & Diabetic neuropathy & $\begin{array}{l}\text { Any (36.0) \# } \\
\text { No } \mathrm{TEAE} \geq 10 \% \text { of patients }\end{array}$ & 0.0 & 3.5 & 28727270 \\
\hline $\begin{array}{l}\text { Markman et al. } \\
2018\end{array}$ & $\begin{array}{l}\text { Parallel-group } \\
\text { Multicenter }\end{array}$ & $\begin{array}{l}\text { Pregabalin 150-600 mg/day (274) } \\
\text { Placebo (265) }\end{array}$ & 3 months & $\begin{array}{l}\text { Post-traumatic neuropathic } \\
\text { pain }\end{array}$ & $\begin{array}{l}\text { Any (50.4) \# } \\
\text { Dizziness (14.6) \# }\end{array}$ & 0.0 & 4.7 & 30242745 \\
\hline $\begin{array}{l}\text { Wanigasekera et al. } \\
2018\end{array}$ & $\begin{array}{l}\text { Crossover-group } \\
\text { Multicenter }\end{array}$ & $\begin{array}{l}\text { Pregabalin 75-300 mg/day (16) } \\
\text { Tramadol 50-400 mg/day (16) } \\
\text { Placebo (16) }\end{array}$ & 1 week & $\begin{array}{l}\text { Post-traumatic neuropathic } \\
\text { pain }\end{array}$ & No safety & No safety & No safety & 29406179 \\
\hline $\begin{array}{l}\text { Ciampi de Andrade et al. } \\
2017\end{array}$ & $\begin{array}{l}\text { Parallel-group } \\
\text { Monocenter }\end{array}$ & $\begin{array}{l}\text { Pregabalin 150-600 mg/day (78) } \\
\text { Placebo (65) }\end{array}$ & $\begin{array}{l}3 \text { days before to } 3 \text { days } \\
\text { after each chemotherapy } \\
\text { infusion (weeks 1-3-5). }\end{array}$ & $\begin{array}{l}\text { Chemotherapy-induced } \\
\text { peripheral neuropathy }\end{array}$ & $\begin{array}{l}\text { Any }(31.0) \# \\
\text { No sufficient detail on frequencies } \\
\text { of patients with TEAEs }\end{array}$ & UK & UK & 28652279 \\
\hline $\begin{array}{l}\text { Schlaeger et al. } \\
2017\end{array}$ & $\begin{array}{l}\text { Parallel-group } \\
\text { Monocenter }\end{array}$ & $\begin{array}{l}\text { Pregabalin 150-600 mg/day (11) } \\
\text { Placebo (11) }\end{array}$ & 3 months & Sickle cell disease & $\begin{array}{l}\text { Any (UK) } \\
\text { Sleepiness (18.2) \# } \\
\text { Dizziness (18.2) \# } \\
\text { Drowsiness (18.2) \# }\end{array}$ & UK & 9.1 & 28843636 \\
\hline Mathieson et al. & Parallel-group & Pregabalin $150-600$ mg/day (180) & 8 weeks & Radiculopathy & Any (64.2)* & 1,9 & 0.0 & 28328324 \\
\hline
\end{tabular}




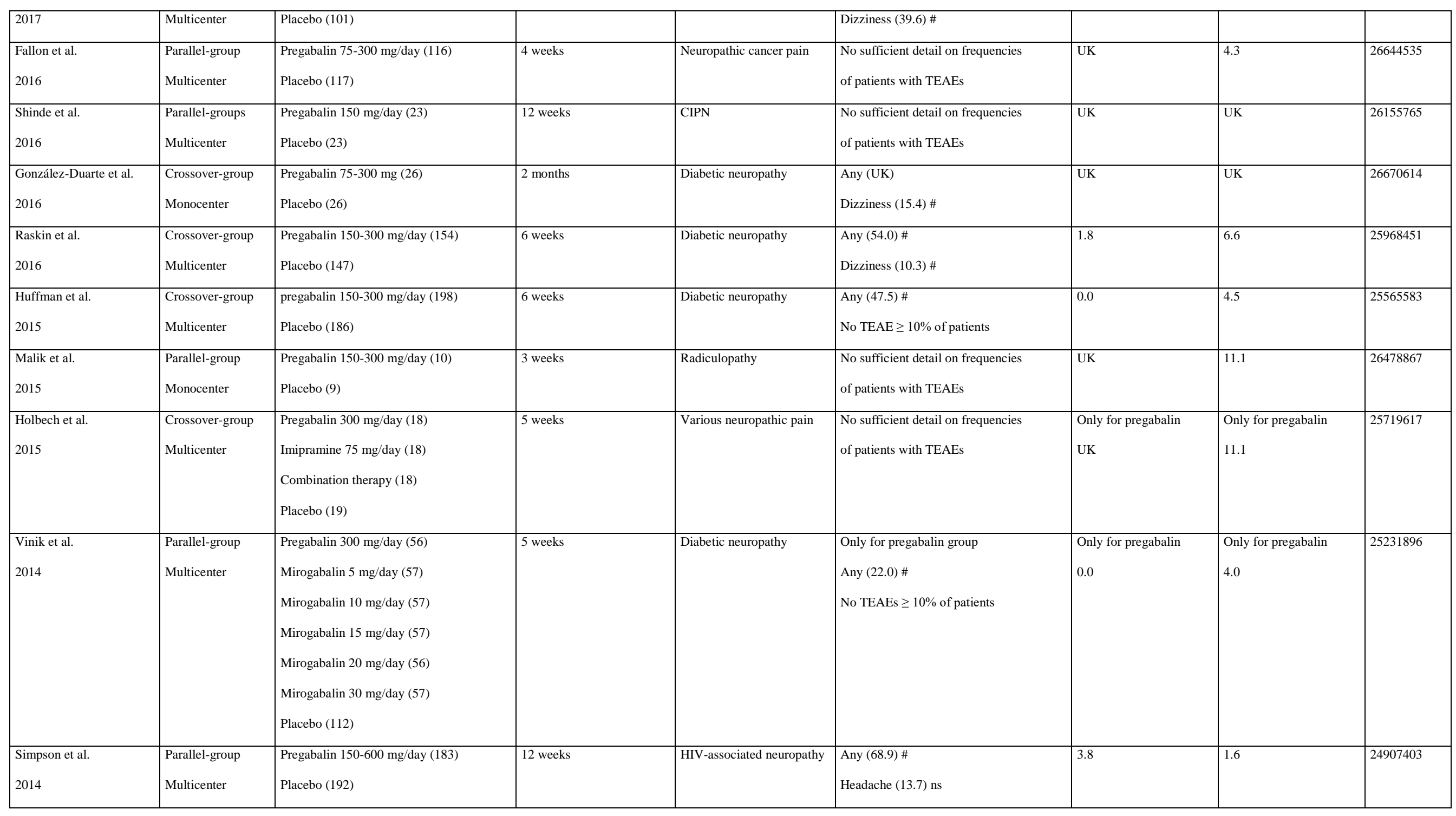




\begin{tabular}{|c|c|c|c|c|c|c|c|c|}
\hline & & & & & Dizziness (13.7) * & & & \\
\hline $\begin{array}{l}\text { Raskin et al. } \\
2014\end{array}$ & $\begin{array}{l}\text { Parallel-group } \\
\text { Multicenter }\end{array}$ & $\begin{array}{l}\text { Pregabalin 150-300 mg/day (147) } \\
\text { Placebo (147) }\end{array}$ & 13 weeks & Diabetic neuropathy & $\begin{array}{l}\text { Any (UK) } \\
\text { No TEAE } \geq 10 \% \text { of patients }\end{array}$ & 0.0 & 1.4 & 23887339 \\
\hline $\begin{array}{l}\text { Smith et al. } \\
2014\end{array}$ & $\begin{array}{l}\text { Parallel-group } \\
\text { Multicenter }\end{array}$ & $\begin{array}{l}\text { Carisbamate } 800 \text { mg/day (94) } \\
\text { Carisbamate } 1200 \text { mg/day (98) } \\
\text { Pregabalin } 300 \text { mg/day (99) } \\
\text { Placebo (95) }\end{array}$ & 15 weeks & Diabetic neuropathy & $\begin{array}{l}\text { Pregabalin } 300 \mathrm{mg} / \text { day (3) } \\
\text { Any (32.0) \# } \\
\text { Somnolence (10.0) \# }\end{array}$ & $\begin{array}{l}\text { Pregabalin } 300 \mathrm{mg} / \text { day } \\
(3.1)\end{array}$ & $\begin{array}{l}\text { Pregabalin } 300 \mathrm{mg} / \mathrm{day} \\
(15.0)\end{array}$ & 23692321 \\
\hline $\begin{array}{l}\text { Rauck et al. } \\
2013\end{array}$ & $\begin{array}{l}\text { Parallel-group } \\
\text { Multicenter }\end{array}$ & $\begin{array}{l}\text { Pregabalin } 300 \text { mg/day (56) } \\
\text { Gabapentin enacarbil } 1200 \text { mg/day (56) } \\
\text { Gabapentin enacarbil } 2400 \text { mg/day (56) } \\
\text { Gabapentin enacarbil } 3600 \text { mg/day (112) } \\
\text { Placebo (112) }\end{array}$ & 12 weeks & Diabetic neuropathy & $\begin{array}{l}\text { Only for pregabalin group } \\
\text { Any (71.0) \# } \\
\text { Dizziness (14.0) \# } \\
\text { Drowsiness (14.0) \# } \\
\text { Peripheral edema (17.0) \# }\end{array}$ & UK & 9.0 & 23186035 \\
\hline $\begin{array}{l}\text { Mishra et al. } \\
2012\end{array}$ & $\begin{array}{l}\text { Parallel-group } \\
\text { Monocenter }\end{array}$ & $\begin{array}{l}\text { Pregabalin 150-600 mg/day (30) } \\
\text { Amitriptyline 50-100 mg/day (30) } \\
\text { Gabapentin 900-1800 md/day (30) } \\
\text { Placebo (30) }\end{array}$ & 4 weeks & Neuropathic cancer pain & $\begin{array}{l}\text { No sufficient detail on frequencies } \\
\text { of patients with TEAEs }\end{array}$ & UK & UK & 21745832 \\
\hline $\begin{array}{l}\text { Jenkins et al. } \\
2012\end{array}$ & $\begin{array}{l}\text { Crossover-group } \\
\text { Multicenter }\end{array}$ & $\begin{array}{l}\text { Pregabalin } 300 \mathrm{mg} / \mathrm{day}(13) \\
\text { Placebo (12) }\end{array}$ & 2 weeks & $\begin{array}{l}\text { Post-traumatic neuropathic } \\
\text { pain }\end{array}$ & $\begin{array}{l}\text { Any (46.0) \# } \\
\text { Dizziness (46.0) \# } \\
\text { Nausea (30.7) \# } \\
\text { Drowsiness (23.0) \# }\end{array}$ & UK & 0.0 & 22888270 \\
\hline $\begin{array}{l}\text { Satoh et al. } \\
2011\end{array}$ & $\begin{array}{l}\text { Parallel-group } \\
\text { Multicenter }\end{array}$ & $\begin{array}{l}\text { Pregabalin } 300 \text { mg/day (134) } \\
\text { Pregabalin } 600 \text { mg/day (45) } \\
\text { Placebo (137) }\end{array}$ & 14 weeks & Diabetic neuropathy & $\begin{array}{l}\text { Pregabalin } 300 \mathrm{mg} \\
\text { Any (57.0) \# } \\
\text { Drowsiness (20.9) \# }\end{array}$ & UK & $\begin{array}{l}\text { Pregabalin } 300 \mathrm{mg} \mathrm{(3.0)} \\
\text { Pregabalin } 600 \mathrm{mg}(17.8)\end{array}$ & 21166852 \\
\hline
\end{tabular}




\begin{tabular}{|c|c|c|c|c|c|c|c|c|}
\hline & & & & & \begin{tabular}{|l} 
Dizziness (19.4) \# \\
Peripheral edema (12.7) \# \\
Weight increased (11.2) \# \\
Pregabalin $600 \mathrm{mg}$ \\
Any (80.0) \# \\
Drowsiness (40.0) \# \\
Dizziness (37.8) \# \\
Peripheral edema (13.3) \# \\
Weight increased (11.1) \#
\end{tabular} & & & \\
\hline $\begin{array}{l}\text { Gilron et al. } \\
2011\end{array}$ & \begin{tabular}{|l|} 
Parallel-group \\
Multicenter
\end{tabular} & \begin{tabular}{|l} 
Pregabalin $450-600 \mathrm{mg} /$ day $(80)$ \\
Placebo (77)
\end{tabular} & 5 weeks & \begin{tabular}{|l|} 
Various neuropathic pain \\
\end{tabular} & $\begin{array}{l}\text { Any }(71.4) \# \\
\text { No TEAE } \geq 10 \% \text { of patients }\end{array}$ & UK & 2.5 & 21178603 \\
\hline $\begin{array}{l}\text { Guan et al. } \\
2011\end{array}$ & $\begin{array}{l}\text { Parallel-group } \\
\text { Multicenter }\end{array}$ & $\begin{array}{l}\text { Pregabalin } 150-600 \mathrm{mg} / \text { day (206) } \\
\text { Placebo (102) }\end{array}$ & 10 weeks & \begin{tabular}{|l} 
Radiculopathy \\
\end{tabular} & $\begin{array}{l}\text { Any }(50.0) \# \\
\text { Dizziness (11.2) \# }\end{array}$ & UK & 5.3 & 21444113 \\
\hline $\begin{array}{l}\text { Simpson et al. } \\
2010\end{array}$ & \begin{tabular}{|l|} 
Parallel-group \\
Multicenter
\end{tabular} & $\begin{array}{l}\text { Pregabalin 150-600 mg/day (151) } \\
\text { Placebo (151) }\end{array}$ & 14 weeks & HIV-associated neuropathy & \begin{tabular}{|l} 
Any (81.5) \# \\
Drowsiness (23.2) \# \\
Dizziness (19.2) \#
\end{tabular} & UK & 6.0 & 20124207 \\
\hline $\begin{array}{l}\text { van Seventer et al. } \\
2010\end{array}$ & $\begin{array}{l}\text { Parallel-group } \\
\text { Multicenter }\end{array}$ & $\begin{array}{l}\text { Pregabalin } 150-600 \mathrm{mg} / \text { day (127) } \\
\text { Placebo (127) }\end{array}$ & 8 weeks & $\begin{array}{l}\text { Post-traumatic neuropathic } \\
\text { pain }\end{array}$ & \begin{tabular}{|l} 
Any (85.8) \# \\
Dizziness (43.3) \# \\
Drowsiness (15.7) \# \\
Headache (11.8) \# \\
Fatigue (11.8) \# \\
Dry mouth (11.0) \#
\end{tabular} & 0.8 & \begin{tabular}{|l|}
19.7 \\
\end{tabular} & 20236172 \\
\hline $\begin{array}{l}\text { Baron et al. } \\
2010\end{array}$ & $\begin{array}{l}\text { Parallel-group } \\
\text { Multicenter }\end{array}$ & $\begin{array}{l}\text { Pregabalin } 150-600 \mathrm{mg} / \text { day (110) } \\
\text { Placebo (107) }\end{array}$ & 46 weeks & \begin{tabular}{|l|} 
Radiculopathy \\
\end{tabular} & \begin{tabular}{|l} 
Any (73.6) \# \\
Dizziness (30.5) \# \\
Drowsiness (12.6) \#
\end{tabular} & 0.0 & \begin{tabular}{|l|}
9.9 \\
\end{tabular} & 20493632 \\
\hline
\end{tabular}




\begin{tabular}{|c|c|c|c|c|c|c|c|c|}
\hline \begin{tabular}{|l} 
Moon et al. \\
2010
\end{tabular} & $\begin{array}{l}\text { Parallel-group } \\
\text { Multicenter }\end{array}$ & $\begin{array}{l}\text { Pregabalin 150-600 mg/day (162) } \\
\text { Placebo (78) }\end{array}$ & 10 weeks & $\begin{array}{l}\text { Chemotherapy-induced } \\
\text { peripheral neuropathy }\end{array}$ & \begin{tabular}{|l} 
Any (50.0)\# \\
Dizziness (21.0) \# \\
Drowsiness (13.6) \#
\end{tabular} & UK & 4.9 & 21353106 \\
\hline \begin{tabular}{|l} 
Arrezo et al. \\
2008
\end{tabular} & \begin{tabular}{|l|} 
Parallel-group \\
Multicenter
\end{tabular} & $\begin{array}{l}\text { Pregabalin } 600 \mathrm{mg} / \text { day }(82) \\
\text { Placebo (85) }\end{array}$ & 12 weeks & Diabetic neuropathy & \begin{tabular}{|l|} 
Any (84.0) \# \\
Peripheral edema (36.6) \# \\
Dizziness (32.9) \# \\
Weight gain (14.6) \# \\
Drowsiness (13.4) \# \\
Fatigue (9.8) \#
\end{tabular} & 0.0 & 17.1 & \begin{tabular}{|l|l|}
18796160 \\
\end{tabular} \\
\hline \begin{tabular}{|l|} 
Tölle et al. \\
2008
\end{tabular} & $\begin{array}{l}\text { Parallel-group } \\
\text { Multicenter }\end{array}$ & $\begin{array}{l}\text { Pregabalin } 150 \text { mg/day (99) } \\
\text { Pregabalin } 300 \mathrm{mg} / \text { day (99) } \\
\text { Pregabalin } 600 \mathrm{mg} / \text { day (101) } \\
\text { Placebo (96) }\end{array}$ & 12 weeks & Diabetic neuropathy & $\begin{array}{l}\text { Pregabalin } 150 \mathrm{mg} \\
\text { Any (UK) } \\
\text { No TEAE } \geq 10 \% \text { of patients } \\
\text { Pregabalin } 300 \mathrm{mg} \\
\text { Any (UK) } \\
\text { No TEAE } \geq 10 \% \text { of patients } \\
\\
\text { Pregabalin } 600 \mathrm{mg} \\
\text { Any (UK) } \\
\text { Dizziness (13.9) \# }\end{array}$ & UK & \begin{tabular}{|l|} 
Pregabalin $150 \mathrm{mg}(5.1)$ \\
Pregabalin $300 \mathrm{mg}(11.1)$ \\
Pregabalin $600 \mathrm{mg}(12.9)$
\end{tabular} & 17631400 \\
\hline \begin{tabular}{|l} 
van Seventer et al. \\
2006
\end{tabular} & \begin{tabular}{|l|} 
Parallel-group \\
Multicenter
\end{tabular} & $\begin{array}{l}\text { Pregabalin } 150 \mathrm{mg}(87) \\
\text { Pregabalin } 300 \mathrm{mg}(98) \\
\text { Pregabalin } 600 \mathrm{mg}(90) \\
\text { Placebo (93) }\end{array}$ & 12 weeks & $\begin{array}{l}\text { Post-herpetic neuropathic } \\
\text { pain }\end{array}$ & $\begin{array}{l}\text { Pregabalin } 150 \mathrm{mg} \\
\text { Any (UK) } \\
\text { Dizziness (16.1) \# } \\
\\
\text { Pregabalin } 300 \mathrm{mg} \\
\text { Any (UK) }\end{array}$ & UK & \begin{tabular}{|l|} 
Pregabalin $150 \mathrm{mg}(8.0)$ \\
Pregabalin $300 \mathrm{mg}(15.3)$ \\
Pregabalin $600 \mathrm{mg}(21.1)$
\end{tabular} & \begin{tabular}{|l|l|}
16466610 \\
\end{tabular} \\
\hline
\end{tabular}




\begin{tabular}{|c|c|c|c|c|c|c|c|c|}
\hline & & & & & $\begin{array}{l}\text { Dizziness (32.7) \# } \\
\text { Peripheral edema (14.3) \# } \\
\text { Drowsiness (11.2) \# } \\
\text { Pregabalin } 600 \mathrm{mg} \\
\text { Any (UK) } \\
\text { Dizziness (36.7) \# } \\
\text { Drowsiness (25.6) \# } \\
\text { Peripheral edema (13.3) \# } \\
\text { Ataxia (12.2) \# } \\
\text { Dry mouth (12.2) \# }\end{array}$ & & & \\
\hline $\begin{array}{l}\text { Richter et al. } \\
2005\end{array}$ & $\begin{array}{l}\text { Parallel-group } \\
\text { Multicenter }\end{array}$ & $\begin{array}{l}\text { Pregabalin } 150 \mathrm{mg} / \text { day }(79) \\
\text { Pregabalin } 600 \mathrm{mg} / \mathrm{day}(82) \\
\text { Placebo (85) }\end{array}$ & 6 weeks & Diabetic neuropathy & $\begin{array}{l}\text { Pregabalin } 150 \mathrm{mg} \\
\text { Any (UK) } \\
\text { Dizziness (10.1) \# } \\
\text { Infection (12.7) \# } \\
\text { Pregabalin } 600 \mathrm{mg} \\
\text { Any (UK) } \\
\text { Dizziness (37.8) \# } \\
\text { Drowsiness (22.0) \# } \\
\text { Peripheral edema (17.1) \# } \\
\text { Headache (15.9) \# } \\
\text { Fatigue (12.2) \# }\end{array}$ & \begin{tabular}{|l|} 
Pregabalin $150 \mathrm{mg}(0.0)$ \\
Pregabalin $600 \mathrm{mg}(8.5)$
\end{tabular} & \begin{tabular}{|l|} 
Pregabalin $150 \mathrm{mg}(2.5)$ \\
Pregabalin $600 \mathrm{mg}(8.5)$
\end{tabular} & 15820913 \\
\hline $\begin{array}{l}\text { Freynhagen et al. } \\
2005\end{array}$ & \begin{tabular}{|l|} 
Parallel-group \\
Multicenter
\end{tabular} & $\begin{array}{l}\text { Pregabalin 150-600 mg/day (141) } \\
\text { Pregabalin } 600 \mathrm{mg} / \text { day (141) } \\
\text { Placebo (65) }\end{array}$ & 12 weeks & Various neuropathic pain & $\begin{array}{l}\text { Pregabalin } 150 \text { - } 600 \mathrm{mg} \\
\text { Any (55.3) \# } \\
\text { Dizziness (19.1) \# }\end{array}$ & UK & $\begin{array}{l}\text { Pregabalin } 150 \text { - } 600 \mathrm{mg} \\
(17.0)\end{array}$ & 15911152 \\
\hline
\end{tabular}




\begin{tabular}{|c|c|c|c|c|c|c|c|c|}
\hline & & & & & $\begin{array}{l}\text { Peripheral edema (15.6) \# } \\
\text { Weight gain (12.1) \# } \\
\text { Drowsiness (10.5) \# } \\
\text { Pregabalin } 600 \mathrm{mg} \\
\text { Any (68.9) \# } \\
\text { Dizziness (28.8) \# } \\
\text { Weight gain (13.6) \# } \\
\text { Drowsiness (12.9) \# } \\
\text { Nausea (10.6) \# }\end{array}$ & & Pregabalin $600 \mathrm{mg}(25.0)$ & \\
\hline $\begin{array}{l}\text { Sabatowski et al. } \\
2004\end{array}$ & $\begin{array}{l}\text { Parallel-group } \\
\text { Multicenter }\end{array}$ & $\begin{array}{l}\text { Pregabalin } 150 \mathrm{mg} / \text { day }(81) \\
\text { Pregabalin } 300 \mathrm{mg} / \text { day }(76) \\
\text { Placebo (81) }\end{array}$ & 8 weeks & 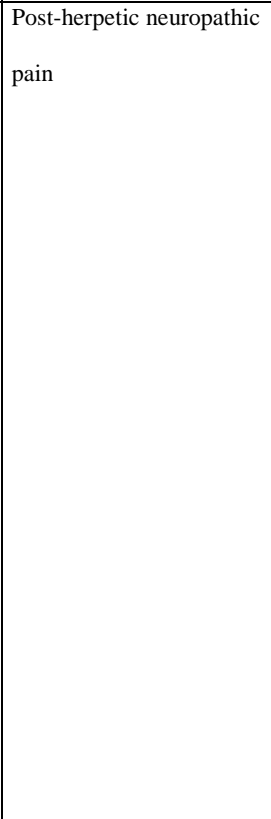 & $\begin{array}{l}\text { Pregabalin 150 mg } \\
\text { Any (UK) } \\
\text { Dizziness (12.0) \# } \\
\text { Drowsiness (15.0) \# } \\
\text { Peripheral edema (3.0) \# } \\
\text { Headache (11.0) \# } \\
\text { Dry mouth (11.0) \# } \\
\text { Pregabalin } 300 \mathrm{mg} \\
\text { Any (83.0) \# } \\
\text { Dizziness (28.0) \# } \\
\text { Drowsiness (24.0) \# } \\
\text { Peripheral edema (13.0) \# } \\
\text { Headache (11.0) \# } \\
\text { Dry mouth (7.0) \# }\end{array}$ & \begin{tabular}{|l|} 
Pregabalin $150 \mathrm{mg}(4.9)$ \\
Pregabalin $300 \mathrm{mg}(1.3)$
\end{tabular} & \begin{tabular}{|l|} 
Pregabalin $150 \mathrm{mg}(11.1)$ \\
Pregabalin $300 \mathrm{mg}(15.8)$
\end{tabular} & 15082123 \\
\hline
\end{tabular}




\begin{tabular}{|c|c|c|c|c|c|c|c|c|}
\hline $\begin{array}{l}\text { Rosenstock et al. } \\
2004\end{array}$ & $\begin{array}{l}\text { Parallel-group } \\
\text { Multicenter }\end{array}$ & \begin{tabular}{|l|} 
Pregabalin $300 \mathrm{mg} /$ day $(76)$ \\
Placebo (70)
\end{tabular} & 8 weeks & Diabetic neuropathy & \begin{tabular}{|l|} 
Any (62.0) \# \\
Dizziness (35.5) \# \\
Drowsiness (19.7) \# \\
Infection (14.5) \# \\
Peripheral edema (10.5) \#
\end{tabular} & UK & 11.0 & 15288403 \\
\hline \begin{tabular}{|l|} 
Lesser et al. \\
2004
\end{tabular} & \begin{tabular}{|l|} 
Parallel-group \\
Multicenter
\end{tabular} & $\begin{array}{l}\text { Pregabalin } 75 \text { mg/day (77) } \\
\text { Pregabalin } 300 \text { mg/day (81) } \\
\text { Pregabalin } 600 \mathrm{mg} / \text { day (82) } \\
\text { Placebo (97) }\end{array}$ & 5 weeks & Diabetic neuropathy & $\begin{array}{l}\text { Pregabalin } 75 \mathrm{mg} \\
\text { Any (UK) } \\
\text { No TEAE } \geq 10 \% \text { of patients } \\
\text { Pregabalin } 300 \mathrm{mg} \\
\text { Any (UK) } \\
\text { Dizziness (27.2) \# } \\
\text { Drowsiness (23.5) \# } \\
\text { Pregabalin } 600 \mathrm{mg} \\
\text { Any (UK) } \\
\text { Dizziness (39.0) \# } \\
\text { Drowsiness (26.8) \# } \\
\text { Peripheral edema (13.4) \# }\end{array}$ & \begin{tabular}{|l} 
Pregabalin $75 \mathrm{mg}$ \\
$(10.4)$ \\
Pregabalin $600 \mathrm{mg}$ \\
$(4.9)$
\end{tabular} & 0.0 & 15596757 \\
\hline \multicolumn{9}{|l|}{\begin{tabular}{|l|} 
Mirogabalin \\
\end{tabular}} \\
\hline \begin{tabular}{|l} 
Baba et al. \\
2019
\end{tabular} & \begin{tabular}{|l} 
Parallel-group \\
Multicenter
\end{tabular} & $\begin{array}{l}\text { Mirogabalin } 15 \text { mg/day (166) } \\
\text { Mirogabalin } 20 \text { mg/day (168) } \\
\text { Mirogabalin } 30 \text { mg/day (166) } \\
\text { Placebo (334) }\end{array}$ & 14 weeks & Diabetic neuropathy & $\begin{array}{l}\text { Mirogabalin } 15 \mathrm{mg} \\
\text { Any (UK) } \\
\text { No TEAE } \geq 10 \% \text { of patients } \\
\text { Mirogabalin } 20 \mathrm{mg}\end{array}$ & 0.0 & $\begin{array}{l}\text { Mirogabalin } 15 \mathrm{mg}(2.4) \\
\text { Mirogabalin } 20 \mathrm{mg}(4.2) \\
\text { Mirogabalin } 30 \mathrm{mg}(9.7)\end{array}$ & 30672128 \\
\hline
\end{tabular}




\begin{tabular}{|c|c|c|c|c|c|c|c|c|}
\hline & & & & & \begin{tabular}{|l} 
Any (UK) \\
No TEAE $\geq 10 \%$ of patients \\
Mirogabalin $30 \mathrm{mg}$ \\
Any (UK) \\
Drowsiness (14.5) ns
\end{tabular} & & & \\
\hline \begin{tabular}{|l} 
Merante et al. \\
2017
\end{tabular} & \begin{tabular}{|l} 
Parallel-group \\
Multicenter
\end{tabular} & $\begin{array}{l}\text { Mirogabalin } 5 \mathrm{mg} / \text { day (55) } \\
\text { Mirogabalin } 10 \mathrm{mg} / \text { day (56) } \\
\text { Mirogabalin } 15 \mathrm{mg} / \text { day (53) } \\
\text { Mirogabalin } 20 \mathrm{mg} / \text { day (56) } \\
\text { Mirogabalin } 30 \mathrm{mg} / \text { day (57) } \\
\text { Pregabalin } 300 \mathrm{mg} / \text { day (50) } \\
\text { Placebo (108) }\end{array}$ & 5 weeks & Diabetic neuropathy & $\begin{array}{l}\text { Only mirogabalin groups } \\
\text { Mirogabalin } 5 \mathrm{mg} \\
\text { Any (10.9) \# } \\
\text { No TEAE } \geq 10 \% \text { of patients } \\
\text { Mirogabalin } 10 \mathrm{mg} \\
\text { Any (19.6) \# } \\
\text { Dizziness (12.5) \# } \\
\text { Mirogabalin } 15 \mathrm{mg} \\
\text { Any (26.4) \# } \\
\text { Dizziness (11.3) \# } \\
\text { Mirogabalin } 20 \mathrm{mg} \\
\text { Any (19.6) \# } \\
\text { No TEAE } \geq 10 \% \text { of patients } \\
\text { Mirogabalin } 30 \mathrm{mg} \\
\text { Any (28.1) \# }\end{array}$ & UK & UK & 28371941 \\
\hline
\end{tabular}




\begin{tabular}{|c|c|c|c|c|c|c|c|c|}
\hline & & & & & Dizziness (15.8) \# & & & \\
\hline \begin{tabular}{|l|} 
Vinik et al. \\
2014
\end{tabular} & \begin{tabular}{|l} 
Parallel-group \\
Multicenter
\end{tabular} & $\begin{array}{l}\text { Mirogabalin } 5 \text { mg/day (57) } \\
\text { Mirogabalin } 10 \text { mg/day (57) } \\
\text { Mirogabalin } 15 \mathrm{mg} / \text { day (57) } \\
\text { Mirogabalin } 20 \text { mg/day (56) } \\
\text { Mirogabalin } 30 \text { mg/day (57) } \\
\text { Pregabalin } 300 \text { mg/day (56) } \\
\text { Placebo (112) }\end{array}$ & 5 weeks & Diabetic neuropathy & $\begin{array}{l}\text { Only mirogabalin groups } \\
\text { Mirogabalin } 5 \mathrm{mg} \\
\text { Any (UK) } \\
\text { Headache (10.9) \# } \\
\text { Mirogabalin } 10 \mathrm{mg} \\
\text { Any (UK) } \\
\text { Dizziness (12.5) \# } \\
\text { Mirogabalin 15mg } \\
\text { Any (UK) } \\
\text { Dizziness (11.3) \# } \\
\text { Mirogabalin } 20 \mathrm{mg} \\
\text { Any (UK) } \\
\text { No TEAE } \geq 10 \% \text { of patients } \\
\text { Mirogabalin } 30 \mathrm{mg} \\
\text { Any (UK) } \\
\text { Dizziness (15.8) \# } \\
\text { Drowsiness (12.3) \# }\end{array}$ & $\begin{array}{l}\text { All mirogabalin groups } \\
(2.9)\end{array}$ & $\begin{array}{l}\text { All mirogabalin groups } \\
(7.2)\end{array}$ & 25231896 \\
\hline
\end{tabular}




\begin{tabular}{|c|c|c|c|c|c|c|c|c|}
\hline \begin{tabular}{|l} 
Bulilete et al. \\
2019
\end{tabular} & $\begin{array}{l}\text { Parallel-group } \\
\text { Multicenter }\end{array}$ & $\begin{array}{l}\text { Gabapentin } 300 \text { - } 1800 \mathrm{mg} / \text { day (33) } \\
\text { Placebo (42) }\end{array}$ & 5 weeks & $\begin{array}{l}\text { Post-herpetic neuropathic } \\
\text { pain }\end{array}$ & $\begin{array}{l}\text { No sufficient detail on frequencies } \\
\text { of patients with TEAEs }\end{array}$ & 0.0 & 6.1 & 31166976 \\
\hline \begin{tabular}{|l} 
Rauck et al. \\
2013
\end{tabular} & \begin{tabular}{|l|} 
Parallel-group \\
Multicenter
\end{tabular} & $\begin{array}{l}\text { Gabapentin enacarbil } 1200 \text { mg/day (56) } \\
\text { Gabapentin enacarbil } 2400 \text { mg/day (56) } \\
\text { Gabapentin enacarbil } 3600 \text { mg/day (112) } \\
\text { Pregabalin } 300 \mathrm{mg} / \text { day (56) } \\
\text { Placebo (112) }\end{array}$ & 12 weeks & Diabetic neuropathy & $\begin{array}{l}\text { Only for Gabapentin enacarbil group } \\
\text { Gabapentin enacarbil } 1200 \mathrm{mg} \\
\text { Any (73.0) \# } \\
\text { Dizziness (15.0) \# } \\
\text { Nausea (11.0) \# } \\
\text { Muscle spasms (10.0) \# } \\
\text { Gabapentin enacarbil } 2400 \mathrm{mg} \\
\text { Any (68.0) \# } \\
\text { Dizziness (14.0) \# } \\
\text { Drowsiness (13.0) \# } \\
\text { Gabapentin enacarbil } 3600 \mathrm{mg} \\
\text { Any (74.0) \# } \\
\text { Dizziness (14.0) \# } \\
\text { Drowsiness (12.0) \# }\end{array}$ & $\begin{array}{l}\text { Only for Gabapentin } \\
\text { enacarbil } \\
(0.0)\end{array}$ & $\begin{array}{l}\text { Only for Gabapentin } \\
\text { enacarbil } \\
\text { Gabapentin enacarbil } \\
1200 \mathrm{mg}(8.0) \\
\text { Gabapentin enacarbil } \\
2400 \mathrm{mg}(21.0) \\
\text { Gabapentin enacarbil } \\
3600 \mathrm{mg}(18.0)\end{array}$ & 23186035 \\
\hline \begin{tabular}{|l} 
Zhang et al. \\
2013
\end{tabular} & \begin{tabular}{|l|} 
Parallel-group \\
Multicenter
\end{tabular} & $\begin{array}{l}\text { Gabapentin enacarbil } 1200 \text { mg/day (107) } \\
\text { Gabapentin enacarbil } 2400 \text { mg/day (82) } \\
\text { Gabapentin enacarbil } 3600 \text { mg/day (87) } \\
\text { Placebo (95) }\end{array}$ & 14 weeks & $\begin{array}{l}\text { Post-herpetic neuropathic } \\
\text { pain }\end{array}$ & $\begin{array}{l}\text { Gabapentin enacarbil } 1200 \mathrm{mg} \\
\text { Any (70.0) \# } \\
\text { Dizziness (17.0)\# } \\
\text { Drowsiness (10.0) \# } \\
\text { Headache (10.0) \# } \\
\text { Gabapentin enacarbil } 2400 \mathrm{mg}\end{array}$ & \begin{tabular}{|l} 
Gabapentin enacarbil \\
$1200 \mathrm{mg}(0.0)$ \\
Gabapentin enacarbil \\
$2400 \mathrm{mg}(0.0)$ \\
Gabapentin enacarbil \\
$3600 \mathrm{mg}(1.1)$
\end{tabular} & $\begin{array}{l}\text { Gabapentin enacarbil } \\
1200 \mathrm{mg}(6.0) \\
\text { Gabapentin enacarbil } \\
2400 \mathrm{mg}(\mathrm{UK}) \\
\text { Gabapentin enacarbil } \\
3600 \mathrm{mg}(18.0)\end{array}$ & 23602345 \\
\hline
\end{tabular}




\begin{tabular}{|c|c|c|c|c|c|c|c|c|}
\hline & & & & & $\begin{array}{l}\text { Any (78.0) \# } \\
\text { Dizziness (26.0) \# } \\
\text { Drowsiness (11.0) \# } \\
\text { Headache (10.0) \# } \\
\text { Gabapentin enacarbil } 3600 \mathrm{mg} \\
\text { Any }(82.0) \# \\
\text { Dizziness (30.0) \# } \\
\text { Drowsiness (14.0) \# } \\
\text { Headache (7.0) \# }\end{array}$ & & & \\
\hline $\begin{array}{l}\text { Sandercock et al. } \\
2012\end{array}$ & $\begin{array}{l}\text { Parallel-group } \\
\text { Multicenter }\end{array}$ & $\begin{array}{l}\text { Gabapentin GR } 3000 \text { mg/day (46) } \\
\text { Gabapentin GR } 1200 \text { mg/day + } 1800 \\
\text { mg/day (50) } \\
\text { Placebo (51) }\end{array}$ & 4 weeks & Diabetic neuropathy & $\begin{array}{l}\text { Gabapentin-GR } 3000 \mathrm{mg} \\
\text { Any (57.4) \# } \\
\text { Dizziness (17.0) \# } \\
\text { Drowsiness (12.8) \# } \\
\text { Gabapentin GR } 1200+1800 \mathrm{mg} \\
\text { Any (46.9) \# } \\
\text { Dizziness (12.2) \# }\end{array}$ & UK & $\begin{array}{l}\text { Gabapentin GR } 3000 \mathrm{mg} \\
(8.7) \\
\text { Gabapentin GR } 1200+ \\
1800 \mathrm{mg}(6.0)\end{array}$ & 22497967 \\
\hline $\begin{array}{l}\text { Mishra et al. } \\
2012\end{array}$ & \begin{tabular}{|l|} 
Parallel-group \\
Monocenter
\end{tabular} & $\begin{array}{l}\text { Amitriptyline } 50 \text { - } 100 \text { mg/day (30) } \\
\text { Gabapentin } 900 \text { - } 1800 \mathrm{mg} / \mathrm{day}(30) \\
\text { Pregabalin } 150 \text { - } 600 \mathrm{mg} / \mathrm{day}(30) \\
\text { Placebo (30) }\end{array}$ & 4 weeks & \begin{tabular}{|l|} 
Neuropathic cancer pain \\
\end{tabular} & No detail on TEAEs frequencies & UK & UK & 21745832 \\
\hline $\begin{array}{l}\text { Hui et al. } \\
2011\end{array}$ & \begin{tabular}{|l} 
Parallel-group \\
Monocenter
\end{tabular} & $\begin{array}{l}\text { Gabapentin } 300 \text { - } 900 \mathrm{mg} / \mathrm{day}(71) \\
\text { Placebo (69) }\end{array}$ & 8 weeks & Carpal tunnel syndrome & No detail on TEAEs frequencies & UK & 7.0 & 21143704 \\
\hline $\begin{array}{l}\text { Wallace et al. } \\
2010\end{array}$ & $\begin{array}{l}\text { Parallel-group } \\
\text { Multicenter }\end{array}$ & Gabapentin ER 1800 mg/day (136) & 10 weeks & $\begin{array}{l}\text { Post-herpetic neuropathic } \\
\text { pain }\end{array}$ & $\begin{array}{l}\text { Gabapentin ER } 1800 \mathrm{mg} \\
\text { Any }(57.0) \#\end{array}$ & $\begin{array}{l}\text { Gabapentin ER } 1800 \mathrm{mg} \\
(3.0)\end{array}$ & $\begin{array}{l}\text { Gabapentin ER } 1800 \mathrm{mg} \\
(12.0)\end{array}$ & 20818838 \\
\hline
\end{tabular}




\begin{tabular}{|c|c|c|c|c|c|c|c|c|}
\hline & & $\begin{array}{l}\text { Gabapentin ER } 600 \mathrm{mg} / \text { day }+1200 \mathrm{mg} / \text { day } \\
\text { (137) } \\
\text { Placebo (134) }\end{array}$ & & & $\begin{array}{l}\text { Dizziness (10.0) \# } \\
\text { Gabapentin ER } 600 \mathrm{mg}+1200 \mathrm{mg} \\
\text { Any (58.0) \# } \\
\text { Dizziness (15.0) \# }\end{array}$ & $\begin{array}{l}\text { Gabapentin ER } 600 \mathrm{mg}+ \\
1200 \mathrm{mg}(5.0)\end{array}$ & $\begin{array}{l}\text { Gabapentin ER } 600 \mathrm{mg}+ \\
1200 \mathrm{mg}(11.0)\end{array}$ & \\
\hline $\begin{array}{l}\text { Amr et al. } \\
2010\end{array}$ & $\begin{array}{l}\text { Parallel-group } \\
\text { Monocenter }\end{array}$ & $\begin{array}{l}\text { Gabapentin } 300 \mathrm{mg} / \text { day (50) } \\
\text { Venlafaxine ER } 37.5 \mathrm{mg} / \mathrm{day}(50) \\
\text { Placebo (50) }\end{array}$ & 10 days & $\begin{array}{l}\text { Post-traumatic neuropathic } \\
\text { pain }\end{array}$ & $\begin{array}{l}\text { No sufficient detail on frequencies } \\
\text { of patients with TEAEs }\end{array}$ & UK & UK & 20473044 \\
\hline $\begin{array}{l}\text { Jensen et al. } \\
2009\end{array}$ & $\begin{array}{l}\text { Parallel-group } \\
\text { Monocenter }\end{array}$ & $\begin{array}{l}\text { Gabapentin } 1800 \text { mg/day (48) } \\
\text { Placebo (48) }\end{array}$ & 4 weeks & $\begin{array}{l}\text { Post-herpetic neuropathic } \\
\text { pain }\end{array}$ & No safety & \begin{tabular}{|l} 
No safety \\
\end{tabular} & No safety & 19590476 \\
\hline $\begin{array}{l}\text { Yelland et al. } \\
2009\end{array}$ & $\begin{array}{l}\text { Crossover-group, } \\
\text { Multicenter }\end{array}$ & $\begin{array}{l}\text { Gabapentin } 600 \text { - } 1800 \text { mg/day (73) } \\
\text { Placebo (73) }\end{array}$ & 2 weeks & Various neuropathic pain & No safety & No safety & No safety & 19453961 \\
\hline $\begin{array}{l}\text { Gordh et al. } \\
2008\end{array}$ & $\begin{array}{l}\text { Crossover-group, } \\
\text { Multicenter }\end{array}$ & $\begin{array}{l}\text { Gabapentin } 600-2400 \mathrm{mg} / \text { day (120) } \\
\text { Placebo (120) }\end{array}$ & 5 weeks & $\begin{array}{l}\text { Post-traumatic neuropathic } \\
\text { pain }\end{array}$ & $\begin{array}{l}\text { Any (UK) } \\
\text { Dizziness (32.5) \# } \\
\text { Fatigue (25.8) \# } \\
\text { Headache (15.0) \# } \\
\text { Confusion (13.3) \# }\end{array}$ & UK & 5.8 & 18258368 \\
\hline $\begin{array}{l}\text { Rao et al. } \\
2007\end{array}$ & $\begin{array}{l}\text { Crossover-group, } \\
\text { Multicenter }\end{array}$ & $\begin{array}{l}\text { Gabapentin } 2700 \text { mg/day (91) } \\
\text { Placebo (89) }\end{array}$ & 6 weeks & $\begin{array}{l}\text { Chemotherapy-induced } \\
\text { peripheral neuropathy }\end{array}$ & $\begin{array}{l}\text { Any (UK) } \\
\text { No TEAE } \geq 10 \% \text { of patients }\end{array}$ & \begin{tabular}{|l|}
0.0 \\
\end{tabular} & 0.0 & 17853395 \\
\hline $\begin{array}{l}\text { Van de Vusse et al. } \\
2004\end{array}$ & $\begin{array}{l}\text { Crossover-group, } \\
\text { Monocenter }\end{array}$ & $\begin{array}{l}\text { Gabapentin 600-1800 mg/day (58) } \\
\text { Placebo (58) }\end{array}$ & 3 weeks & $\begin{array}{l}\text { Complex regional pain } \\
\text { syndrome }\end{array}$ & $\begin{array}{l}\text { Any }(62.1) \# \\
\text { Dizziness }(37.3) * \\
\text { Drowsiness }(27.8) * \\
\text { Lethargy }(20.4) * \\
\text { Nausea (18.5) ns }\end{array}$ & UK & 5.2 & 15453912 \\
\hline $\begin{array}{l}\text { Serpell et al. } \\
2002\end{array}$ & $\begin{array}{l}\text { Parallel-group } \\
\text { Multicenter }\end{array}$ & $\begin{array}{l}\text { Gabapentin } 2400 \mathrm{mg} / \text { day (153) } \\
\text { Placebo (152) }\end{array}$ & 8 weeks & Various neuropathic pain & $\begin{array}{l}\text { Any (76.5) \# } \\
\text { Dizziness (24.2)\# }\end{array}$ & 2.6 & 15.7 & 12406532 \\
\hline
\end{tabular}




\begin{tabular}{|c|c|c|c|c|c|c|c|c|}
\hline & & & & & Drowsiness (14.4) \# & & & \\
\hline $\begin{array}{l}\text { Bone et al. } \\
2002\end{array}$ & $\begin{array}{l}\text { Crossover-group, } \\
\text { Multicenter }\end{array}$ & $\begin{array}{l}\text { Gabapentin 300-2400 } \mathrm{mg} / \mathrm{day}(8) \\
\text { Placebo (6) }\end{array}$ & 6 weeks & Phantom Limb Pain & \begin{tabular}{|l} 
Any (UK) \\
Drowsiness (87.5) ns \\
Dizziness (25.0) ns \\
Headache (25.0) ns \\
Nausea 12.5) ns
\end{tabular} & UK & 0.0 & 12373695 \\
\hline
\end{tabular}

Table 1: Summary table for gabapentinoids

TEAE, treatment-emergent adverse event; ER, extended-release; GR, Gastroretentive; SAEs, serious adverse event; UK, unknown.

Route of administration is not provided when administered orally.

* Statistically different from placebo; ns, no statistical difference from placebo; \#, no statistical comparison to placebo 


\begin{tabular}{|c|c|c|c|c|c|c|c|c|}
\hline Authors' names & Study design & $\begin{array}{l}\text { Drug/comparator and dose } \\
\text { (patient number) }\end{array}$ & Duration & Pathology & $\begin{array}{l}\text { List of TEAEs in study drug } \\
\text { arm } \\
\text { ( } \geq 10 \% \text { of patients })\end{array}$ & $\begin{array}{l}\text { SAEs related to } \\
\text { study drug }(\%)\end{array}$ & $\begin{array}{l}\text { Dropout due to } \\
\text { TEAE in study drug } \\
\text { arm (\%) }\end{array}$ & $\begin{array}{l}\text { Reference } \\
\text { (PMID) }\end{array}$ \\
\hline \multicolumn{9}{|l|}{ Lamotrigine } \\
\hline $\begin{array}{l}\text { Rao et al. } \\
2008\end{array}$ & $\begin{array}{l}\text { Parallel-group } \\
\text { Multicenter }\end{array}$ & $\begin{array}{l}\text { Lamotrigine } 300 \text { mg/day (63) } \\
\text { Placebo (62) }\end{array}$ & 10 weeks & $\begin{array}{l}\text { Chemotherapy-induced } \\
\text { peripheral neuropathy }\end{array}$ & No TEAE $\geq 10 \%$ of patients & UK & 11.1 & 18428211 \\
\hline $\begin{array}{l}\text { Silver et al. } \\
2007\end{array}$ & $\begin{array}{l}\text { Parallel-group } \\
\text { Multicenter }\end{array}$ & $\begin{array}{l}\text { Lamotrigine } 200 \text { - } 400 \text { mg/day (111) } \\
\text { placebo (109) }\end{array}$ & 14 weeks & Various neuropathic pain & $\begin{array}{l}\text { Any (71.0) \# } \\
\text { Rash (18.0) \# }\end{array}$ & 0.0 & 24.0 & 17662571 \\
\hline $\begin{array}{l}\text { Simpson et al. } \\
2003\end{array}$ & $\begin{array}{l}\text { Parallel-group } \\
\text { Multicenter }\end{array}$ & $\begin{array}{l}\text { Lamotrigine } 600 \mathrm{mg} / \mathrm{day}(150) \\
\text { Placebo (77) }\end{array}$ & 12 weeks & HIV-associated neuropathy & $\begin{array}{l}\text { Any (UK) } \\
\text { Rash (14.0) \# } \\
\text { Infection (11.0) \# } \\
\text { Nausea (11.0) \# } \\
\text { Diarrhea (11.0) \# } \\
\text { Headache (11.0) \# }\end{array}$ & 0.0 & 6.7 & \begin{tabular}{|l|}
12743240 \\
\end{tabular} \\
\hline \multicolumn{9}{|l|}{ Lacosamide } \\
\hline $\begin{array}{l}\text { de Greef BTA et al. } \\
2019\end{array}$ & $\begin{array}{l}\text { Crossover-group, } \\
\text { Monocenter }\end{array}$ & $\begin{array}{l}\text { Lacosamide } 400 \text { mg/day (24) } \\
\text { Placebo (23) }\end{array}$ & 14 weeks & Small fiber neuropathy & \begin{tabular}{|l} 
Any (87.5) \# \\
Dizziness (41.7) \# \\
headache (25) \# \\
Nausea (25) \# \\
fatigue (20.8) \# \\
tremor (20.8) \# \\
Drowsiness (16.7) \# \\
epigastric pain (16.7) \# \\
memory impaired (12.5) \#
\end{tabular} & 4.2 & 0.0 & 30649227 \\
\hline
\end{tabular}




\begin{tabular}{|c|c|c|c|c|c|c|c|c|}
\hline & & & & & pruritus (12.5) \# & & & \\
\hline \begin{tabular}{|l} 
Ziegler et al. \\
2010
\end{tabular} & \begin{tabular}{|l} 
Parallel-group \\
Multicenter
\end{tabular} & $\begin{array}{l}\text { Lacosamide } 400 \mathrm{mg} / \mathrm{day}(150) \\
\text { Lacosamide } 600 \mathrm{mg} / \mathrm{day}(133) \\
\text { Placebo (74) }\end{array}$ & 18 weeks & \begin{tabular}{|l|l|} 
Diabetic neuropathy \\
\end{tabular} & \begin{tabular}{|l} 
Lacosamide $400 \mathrm{mg}$ \\
Any (58.7) \# \\
Fatigue (10.0) \# \\
\\
Lacosamide $600 \mathrm{mg}$ \\
Any (64.7) \# \\
Dizziness (19.5) \# \\
Nausea (11.3) \#
\end{tabular} & \begin{tabular}{|l|} 
Lacosamide $400 \mathrm{mg}(7.3)$ \\
Lacosamide $600 \mathrm{mg}(8.3)$
\end{tabular} & \begin{tabular}{|l}
13.0 (both groups) \\
\end{tabular} & 20067958 \\
\hline \begin{tabular}{|l} 
Wymer et al. \\
2009
\end{tabular} & \begin{tabular}{|l|} 
Parallel-group \\
Multicenter
\end{tabular} & $\begin{array}{l}\text { Lacosamide200 mg/day (93) } \\
\text { Lacosamide } 400 \text { mg/day (93) } \\
\text { Lacosamide } 600 \text { mg/day (93) } \\
\text { Placebo (93) }\end{array}$ & 12 weeks & Diabetic neuropathy & $\begin{array}{l}\text { Lacosamide } 200 \mathrm{mg} \\
\text { Any (75.3) \# } \\
\text { Dizziness (10.8) \# } \\
\text { Lacosamide } 400 \mathrm{mg} \\
\text { Any (78.0) \# } \\
\text { Dizziness (15.4) \# } \\
\text { Lacosamide } 600 \mathrm{mg} \\
\text { Any (89.2) \# } \\
\text { Dizziness (35.5) \# } \\
\text { Nausea (15.1) \# } \\
\text { Fatigue (15.1) \# }\end{array}$ & UK & $\begin{array}{l}\text { Lacosamide200 mg (8.6) } \\
\text { Lacosamide } 400 \mathrm{mg}(23.1) \\
\text { Lacosamide } 600 \mathrm{mg}(39.8)\end{array}$ & 19454870 \\
\hline \begin{tabular}{|l} 
Shaibani et al. \\
2009
\end{tabular} & \begin{tabular}{|l} 
Parallel-group \\
Multicenter
\end{tabular} & $\begin{array}{l}\text { Lacosamide200 mg/day (141) } \\
\text { Lacosamide } 400 \mathrm{mg} / \mathrm{day} \text { (125) } \\
\text { Lacosamide } 600 \mathrm{mg} / \mathrm{day} \text { (137) } \\
\text { Placebo (65) }\end{array}$ & 12 weeks & Diabetic neuropathy & $\begin{array}{l}\text { Lacosamide } 200 \mathrm{mg} \\
\text { Any }(80.1) \# \\
\text { No TEAE } \geq 10 \% \text { of patients }\end{array}$ & UK & $\begin{array}{l}\text { Lacosamide } 200 \mathrm{mg}(12.1) \\
\text { Lacosamide } 400 \mathrm{mg}(24.0)\end{array}$ & 19409861 \\
\hline
\end{tabular}




\begin{tabular}{|c|c|c|c|c|c|c|c|c|}
\hline & & & & & $\begin{array}{l}\text { Lacosamide } 400 \mathrm{mg} \\
\text { Any (79.2) \# } \\
\text { Dizziness (21.6) \# } \\
\text { Lacosamide } 600 \mathrm{mg} \\
\text { Any (86.9) \# } \\
\text { Dizziness (28.5) \# } \\
\text { Nausea (18.2) \# } \\
\text { Tremor (14.6) \# } \\
\text { Headache (13.1) \# }\end{array}$ & & Lacosamide $600 \mathrm{mg}(42.3)$ & \\
\hline $\begin{array}{l}\text { Rauck et al. } \\
2007\end{array}$ & $\begin{array}{l}\text { Parallel-group } \\
\text { Multicenter }\end{array}$ & $\begin{array}{l}\text { Lacosamide } 100-400 \mathrm{mg} / \text { day (60) } \\
\text { Placebo (59) }\end{array}$ & 7 weeks & Diabetic neuropathy & $\begin{array}{l}\text { Any }(87.0) \# \\
\text { Dizziness (15.0) \# } \\
\text { Nausea (12.0) \# } \\
\text { Back pain (10.0) \# } \\
\text { Headache (18.0) \# } \\
\text { Upper respiratory tract symptoms (25.0) \# }\end{array}$ & \begin{tabular}{|l|}
7.0 \\
\end{tabular} & 8.3 & 17237664 \\
\hline \multicolumn{9}{|c|}{ Levetiracetam } \\
\hline $\begin{array}{l}\text { Holbech et al. } \\
2011\end{array}$ & $\begin{array}{l}\text { Crossover-group, } \\
\text { Multicenter }\end{array}$ & $\begin{array}{l}\text { Levetiracetam } 3000 \text { mg/day (21) } \\
\text { Placebo (18) }\end{array}$ & 6 weeks & Various neuropathic pain & \begin{tabular}{|l} 
Any (UK) \\
Fatigue (17.7) ns
\end{tabular} & \begin{tabular}{|l|}
0.0 \\
\end{tabular} & \begin{tabular}{|l|}
7.7 \\
\end{tabular} & 21183370 \\
\hline $\begin{array}{l}\text { Vilholm et al. } \\
2008\end{array}$ & $\begin{array}{l}\text { Crossover-group, } \\
\text { Monocenter }\end{array}$ & $\begin{array}{l}\text { Levetiracetam } 3000 \text { mg/day (27) } \\
\text { Placebo (27) }\end{array}$ & 4 weeks & $\begin{array}{l}\text { Post-traumatic neuropathic } \\
\text { pain }\end{array}$ & \begin{tabular}{|l} 
Any $(56.0) \#$ \\
Fatigue (40.0) \# \\
Dizziness (12.0) \# \\
Headache (12.0) \# \\
Gastric upset (12.0) \#
\end{tabular} & UK & \begin{tabular}{|l|l}
6.7 \\
\end{tabular} & 18565107 \\
\hline
\end{tabular}




\begin{tabular}{|c|c|c|c|c|c|c|c|c|}
\hline $\begin{array}{l}\text { Agrawal et al. } \\
2009\end{array}$ & $\begin{array}{l}\text { Parallel-group } \\
\text { Monocenter }\end{array}$ & $\begin{array}{l}\text { Sodium valproate } 20 \mathrm{mg} / \mathrm{kg} / \text { day (20) } \\
\text { Placebo (21) }\end{array}$ & 12 weeks & Diabetic neuropathy & \begin{tabular}{|l} 
Any (UK) \\
Nausea (10.0) \#
\end{tabular} & UK & 0.0 & 19208440 \\
\hline \multicolumn{9}{|l|}{ Zonisamide } \\
\hline $\begin{array}{l}\text { Atli et al. } \\
2005\end{array}$ & $\begin{array}{l}\text { Parallel-group } \\
\text { Monocenter }\end{array}$ & $\begin{array}{l}\text { Zonisamide } 540 \mathrm{mg} / \mathrm{day} \text { (13) } \\
\text { Placebo (12) }\end{array}$ & 12 weeks & Diabetic neuropathy & $\begin{array}{l}\text { Any (91.7) ns } \\
\text { Urinary (25.0) ns } \\
\text { Cardiovascular (25.0) ns } \\
\text { Dermatological (33.3) ns } \\
\text { Musculoskeletal (25.0) ns } \\
\text { Headache (16.7) ns } \\
\text { Dizziness (25.0) ns } \\
\text { Drowsiness/sleepiness (16.7) ns } \\
\text { Restless/insomnia (25.0) ns } \\
\text { Respiratory (33.3) ns } \\
\text { Special senses (16.7) ns }\end{array}$ & 8.3 & 8.3 & 15972086 \\
\hline \multicolumn{9}{|c|}{ Ethosuximide } \\
\hline $\begin{array}{l}\text { Kerckhove et al. } \\
2018\end{array}$ & $\begin{array}{l}\text { Parallel-group } \\
\text { Multicenter }\end{array}$ & $\begin{array}{l}\text { Ethosuximide } 250-1500 \text { mg/day (59) } \\
\text { Placebo (55) }\end{array}$ & 6 weeks & Various neuropathic pain & $\begin{array}{l}\text { Any (69.5) \# } \\
\text { Headache (32.0) \# } \\
\text { Dyspepsia (39.0) \# } \\
\text { Dizziness (20.3) \# } \\
\text { Insomnia (11.9) \# } \\
\text { Skin rash (11.9) \# } \\
\text { Drowsiness (10.2) \# } \\
\text { Vomiting (10.2) \# }\end{array}$ & 6.8 & 59.3 & 29577519 \\
\hline
\end{tabular}




\begin{tabular}{|c|c|c|c|c|c|c|c|c|}
\hline $\begin{array}{l}\text { Smith et al. } \\
2014\end{array}$ & $\begin{array}{l}\text { Study } 1 \\
\text { Crossover-group, } \\
\text { Multicenter } \\
\text { Study 2: } \\
\text { Crossover-group, } \\
\text { Multicenter } \\
\text { Study 3: } \\
\text { Parallel-group } \\
\text { Multicenter }\end{array}$ & $\begin{array}{l}\text { Study1 } \\
\text { Carisbamate } 400 \mathrm{mg} / \text { day (84) } \\
\text { Placebo (89) } \\
\text { Study 2: } \\
\text { Carisbamate } 400 \text { mg/day (131) } \\
\text { Placebo (133) } \\
\text { Study 3: } \\
\text { Carisbamate } 800 \text { mg/day (94) } \\
\text { Carisbamate } 1200 \text { mg/day (98) } \\
\text { Pregabalin } 300 \text { mg/day (99) } \\
\text { Placebo (95) }\end{array}$ & $\begin{array}{l}\text { Study 1: } 8 \text { weeks } \\
\text { Study 2: } 8 \text { weeks } \\
\text { Study 3: } 15 \text { weeks }\end{array}$ & $\begin{array}{l}\text { Study 1: Post-herpetic } \\
\text { neuropathic pain } \\
\text { Study 2: Diabetic } \\
\text { neuropathy } \\
\text { Study 3: Diabetic } \\
\text { neuropathy }\end{array}$ & $\begin{array}{l}\text { Study } 1 \\
\text { Any (27) \# } \\
\text { Dizziness (12) \# } \\
\text { Headache (12) \# } \\
\text { Study } 2 \\
\text { Any (15) \# } \\
\text { No TEAE } \geq 10 \% \text { of patients } \\
\text { Study } 3 \\
\text { Carisbamate } 800 \mathrm{mg} / \mathrm{day} \\
\text { Any (38) \# } \\
\text { Dizziness (14) \# } \\
\text { Headache (13) \# } \\
\text { Carisbamate 1200 mg/day } \\
\text { Any (35) \# } \\
\text { Dizziness (13) \# } \\
\text { Somnolence (10) \# }\end{array}$ & $\begin{array}{l}\text { Study } 1 \\
\text { None } \\
\text { Study } 2 \\
2 \\
\text { Study } 3 \\
\text { Carisbamate } 800 \mathrm{mg} / \mathrm{day} \\
\text { (4) } \\
\text { Carisbamate } 1200 \mathrm{mg} / \mathrm{day} \\
\text { (3) }\end{array}$ & $\begin{array}{l}\text { Study } 1 \\
1 \\
\text { Study } 2 \\
1 \\
\text { Study } 3 \\
\text { Carisbamate } 800 \mathrm{mg} / \mathrm{day} \\
\text { (15) } \\
\text { Carisbamate } 1200 \mathrm{mg} / \text { day } \\
\text { (14) }\end{array}$ & 23692321 \\
\hline \multicolumn{9}{|c|}{ Carbamazepine } \\
\hline $\begin{array}{l}\text { Harke et al. } \\
2001\end{array}$ & $\begin{array}{l}\text { Crossover-group } \\
\text { Monocenter }\end{array}$ & $\begin{array}{l}\text { Carbamazepine } 600 \text { to } 400 \mathrm{mg} / \mathrm{d}(22) \\
\text { Placebo (21) }\end{array}$ & 8 days & $\begin{array}{l}\text { Neuropathic pain } \\
\text { Complex regional pain } \\
\text { syndrome I }\end{array}$ & $\begin{array}{l}\text { Any (UK)\# } \\
\text { Daily description of adverse effects }\end{array}$ & UK & \begin{tabular}{|l|}
13.6 \\
\end{tabular} & 11159256 \\
\hline
\end{tabular}




\begin{tabular}{|c|c|c|c|c|c|c|c|c|}
\hline \begin{tabular}{|l} 
Demant et al. \\
2014
\end{tabular} & $\begin{array}{l}\text { Crossover-group, } \\
\text { Monocenter }\end{array}$ & $\begin{array}{l}\text { Oxcarbazepine 1800-2400 mg/day (47) } \\
\text { Placebo (50) }\end{array}$ & 6 weeks & Various neuropathic pain & $\begin{array}{l}\text { Any (94.0) \# } \\
\text { Dizziness (67.0) \# } \\
\text { Tiredness (47.0) \# } \\
\text { Headache (24.0) \# } \\
\text { Nausea (36.0) \# } \\
\text { Vomiting (16.0) \# } \\
\text { Diplopia (19.0) \# }\end{array}$ & UK & 17.7 & 25139589 \\
\hline $\begin{array}{l}\text { Dogra et al. } \\
2005\end{array}$ & $\begin{array}{l}\text { Parallel-group } \\
\text { Multicenter }\end{array}$ & $\begin{array}{l}\text { Oxcarbazepine 300-1800 mg/day (69) } \\
\text { Placebo (77) }\end{array}$ & 16 weeks & \begin{tabular}{|l} 
Diabetic neuropathy \\
\end{tabular} & \begin{tabular}{|l} 
Any (UK) \\
Dizziness (44.9) \# \\
Headache (24.6) \# \\
Nausea (23.2) \# \\
Drowsiness (11.6) \# \\
Fatigue (11.6) \#
\end{tabular} & 2.9 & 27.5 & 16139183 \\
\hline
\end{tabular}

Table 2: Summary table of other antiepileptics

TEAE, treatment-emergent adverse event; SAEs, serious adverse event; UK, unknown;

Route of administration is not provided when administered orally.

* statistically different from placebo ; ns no statistically different from placebo; \# no statistically compared to placebo 


\begin{tabular}{|c|c|c|c|c|c|c|c|c|}
\hline Authors' names & Study design & $\begin{array}{l}\text { Drug/comparator and dose } \\
\text { (patient number) }\end{array}$ & Duration & Pathology & $\begin{array}{l}\text { List of TEAEs in study drug } \\
\text { arm } \\
(\geq 10 \% \text { of patients) }\end{array}$ & $\begin{array}{l}\text { SAEs related to } \\
\text { study drug }(\%)\end{array}$ & $\begin{array}{l}\text { Dropout due to } \\
\text { TEAE in study drug } \\
\text { arm }(\%)\end{array}$ & $\begin{array}{l}\text { Reference } \\
\text { (PMID) }\end{array}$ \\
\hline \multicolumn{9}{|l|}{ Duloxetine } \\
\hline $\begin{array}{l}\text { Schukro et al. } \\
2016\end{array}$ & $\begin{array}{l}\text { Crossover-group, } \\
\text { Monocenter }\end{array}$ & $\begin{array}{l}\text { Duloxetine } 120 \mathrm{mg} / \text { day (31) } \\
\text { Placebo (29) }\end{array}$ & 4 weeks & Radiculopathy & $\begin{array}{l}\text { Any (65.0) \# } \\
\text { Sweating (35.0) ns } \\
\text { Dry mouth (35.0) * } \\
\text { Fatigue (26.0) ns } \\
\text { Nausea (19.0) ns } \\
\text { Constipation (19.0) ns } \\
\text { Loss of appetite (19.0) * } \\
\text { Dizziness (16.0) ns }\end{array}$ & UK & 19.35 & 26517858 \\
\hline $\begin{array}{l}\text { Gao et al. } \\
2015\end{array}$ & $\begin{array}{l}\text { Parallel-group } \\
\text { Multicenter }\end{array}$ & $\begin{array}{l}\text { Duloxetine } 60 \mathrm{mg} \text { qd (203) } \\
\text { Placebo (202) }\end{array}$ & 12 weeks & Diabetic neuropathy & $\begin{array}{l}\text { Any }(46.5) * \\
\text { Nausea (10.4) * }\end{array}$ & 1.5 & 8.4 & 25939897 \\
\hline $\begin{array}{l}\text { Harrison et al. } \\
2013\end{array}$ & $\begin{array}{l}\text { Crossover-group, } \\
\text { Monocenter }\end{array}$ & $\begin{array}{l}\text { Duloxetine } 60 \mathrm{mg} / \text { day (15) } \\
\text { Methadone } 10 \mathrm{mg} / \text { day (15) } \\
\text { Duloxetine } 60 \mathrm{mg} / \text { day + Methadone } 10 \mathrm{mg} / \text { day } \\
(15) \\
\text { Placebo (15) }\end{array}$ & 4 weeks & $\begin{array}{l}\text { HIV-associated } \\
\text { neuropathy }\end{array}$ & $\begin{array}{l}\text { Only for duloxetine group } \\
\text { Any }(40.0) \#\end{array}$ & 6.7 & UK & 23565581 \\
\hline $\begin{array}{l}\text { Smith et al. } \\
2013\end{array}$ & $\begin{array}{l}\text { Crossover-group, } \\
\text { Multicenter }\end{array}$ & $\begin{array}{l}\text { Duloxetine } 60 \mathrm{mg} / \mathrm{day}(220) \\
\text { Placebo (220) }\end{array}$ & 5 weeks & $\begin{array}{l}\text { Chemotherapy- } \\
\text { induced peripheral } \\
\text { neuropathy }\end{array}$ & Any (UK) & 0.0 & 8.4 & 23549581 \\
\hline $\begin{array}{l}\text { Yasuda et al. } \\
2011\end{array}$ & $\begin{array}{l}\text { Parallel-group } \\
\text { Multicenter }\end{array}$ & $\begin{array}{l}\text { Duloxetine } 40 \text { mg/day (86) } \\
\text { Duloxetine } 60 \text { mg/day (86) } \\
\text { Placebo (167) }\end{array}$ & 12 weeks & Diabetic neuropathy & $\begin{array}{l}\text { Duloxetine } 40 \mathrm{mg} \\
\text { Any }(84.7) * \\
\text { Drowsiness (18.8) ns }\end{array}$ & Duloxetine $40 \mathrm{mg}: 3.5$ & Duloxetine $40 \mathrm{mg}: 10.5$ & 24843472 \\
\hline
\end{tabular}




\begin{tabular}{|c|c|c|c|c|c|c|c|c|}
\hline & & & & & \begin{tabular}{|l} 
Nausea (11.8) ns \\
Duloxetine $60 \mathrm{mg}$ \\
Any (84.9)* \\
Drowsiness (24.4) ns \\
Nausea (16.3) ns
\end{tabular} & Duloxetine $60 \mathrm{mg}: 2.3$ & Duloxetine $60 \mathrm{mg}: 14.0$ & \\
\hline \begin{tabular}{|l} 
Ziegler et al. \\
2007
\end{tabular} & \begin{tabular}{|l} 
Parallel-group \\
Multicenter
\end{tabular} & $\begin{array}{l}\text { Duloxetine } 60 \text { mg/day (344) } \\
\text { Duloxetine } 120 \text { mg/day (341) } \\
\text { Placebo (339) }\end{array}$ & 12 weeks & Diabetic neuropathy & \begin{tabular}{|l} 
Duloxetine $60 \mathrm{mg}$ \\
Any (UK) \\
Nausea $(24.0)$ * \\
Drowsiness $(15.0)$ * \\
Dizziness $(11.0)$ * \\
Diarrhea (11.0) * \\
\\
Duloxetine $120 \mathrm{mg}$ \\
Any (UK) \\
Nausea (27.0) * \\
Drowsiness $(19.0)$ * \\
Dizziness $(13.0) *$ \\
Constipation $(12.0) *$ \\
Fatigue $(11.0)$ * \\
Hyperhidrosis $(10.0)$ * \\
Dry mouth (10.0) *
\end{tabular} & UK & UK & 17327338 \\
\hline $\begin{array}{l}\text { Wernicke et al. } \\
2006\end{array}$ & \begin{tabular}{|l} 
Parallel-group \\
Multicenter
\end{tabular} & $\begin{array}{l}\text { Duloxetine } 60 \mathrm{mg} / \mathrm{day}(114) \\
\text { Duloxetine } 120 \mathrm{mg} / \mathrm{day}(112) \\
\text { Placebo (108) }\end{array}$ & 12 weeks & Diabetic neuropathy & $\begin{array}{l}\text { Duloxetine } 60 \mathrm{mg} \\
\text { Any }(89.5) * \\
\text { Nausea }(28.1) * \\
\text { Dizziness }(15.8) *\end{array}$ & \begin{tabular}{|l|l|} 
Duloxetine $60 \mathrm{mg}: 4.4$ \\
\end{tabular} & Duloxetine $60 \mathrm{mg}: 14.9$ & 17060567 \\
\hline
\end{tabular}




\begin{tabular}{|c|c|c|c|c|c|c|c|c|}
\hline & & & & & \begin{tabular}{|l} 
Fatigue $(12.3)$ * \\
Headache $(10.5)$ ns \\
Diarrhoea $13(11.4)$ * \\
Duloxetine $120 \mathrm{mg}$ \\
Any $(85.7) *$ \\
Nausea $(32.1)$ * \\
Drowsiness (15.2) * \\
Constipation (18.8) * \\
Headache (13.4) ns \\
Fatigue (12.5) * \\
Dizziness (10.7) ns
\end{tabular} & Duloxetine $120 \mathrm{mg}: 1.8$ & Duloxetine $120 \mathrm{mg}: 17.9$ & \\
\hline \begin{tabular}{|l} 
Goldstein et al. \\
2005
\end{tabular} & \begin{tabular}{|l} 
Parallel-group \\
Multicenter
\end{tabular} & \begin{tabular}{|l|} 
Duloxetine $20 \mathrm{mg} / \mathrm{d}(115)$ \\
Duloxetine $60 \mathrm{mg} / \mathrm{d}$ (114) \\
Duloxetine $120 \mathrm{mg} / \mathrm{d}(113)$ \\
Placebo (115)
\end{tabular} & 12 weeks & Diabetic neuropathy & \begin{tabular}{|l} 
Duloxetine $20 \mathrm{mg}$ \\
Any (UK) \\
Nausea (13.9) ns \\
Duloxetine $60 \mathrm{mg}$ \\
Any (UK) \\
Nausea (16.7) ns \\
Drowsiness (20.2) * \\
Constipation (14.9) * \\
\\
Duloxetine $120 \mathrm{mg}$ \\
Any (UK) \\
Nausea (27.4) * \\
Drowsiness (28.3) *
\end{tabular} & \begin{tabular}{|l} 
Duloxetine $20 \mathrm{mg}: 1.7$ \\
Duloxetine $60 \mathrm{mg}: 0.0$ \\
Duloxetine $120 \mathrm{mg}: 1.8$
\end{tabular} & \begin{tabular}{|l} 
Duloxetine $20 \mathrm{mg}: 4.3$ \\
Duloxetine $60 \mathrm{mg}: 13.2$ \\
Duloxetine $120 \mathrm{mg}: 19.5$
\end{tabular} & 15927394 \\
\hline
\end{tabular}




\begin{tabular}{|c|c|c|c|c|c|c|c|c|}
\hline & & & & & $\begin{array}{l}\text { Dizziness }(23.0) * \\
\text { Constipation }(10.6) * \\
\text { Dry mouth }(15.0) * \\
\text { Decreased appetite (12.4) * }\end{array}$ & & & \\
\hline $\begin{array}{l}\text { Raskin et al. } \\
2005\end{array}$ & $\begin{array}{l}\text { Parallel-group } \\
\text { Multicenter }\end{array}$ & $\begin{array}{l}\text { Duloxetine } 60 \text { mg/day (116) } \\
\text { Duloxetine } 120 \text { mg/day (116) } \\
\text { Placebo (116) }\end{array}$ & 12 weeks & Diabetic neuropathy & $\begin{array}{l}\text { Duloxetine } 60 \mathrm{mg} \\
\text { Any (61.2) ns } \\
\text { Duloxetine } 120 \mathrm{mg} \\
\text { Any (62.9)* }\end{array}$ & $\begin{array}{l}\text { Duloxetine } 60 \mathrm{mg}: 3.4 \\
\text { Duloxetine } 120 \mathrm{mg}: 1.7\end{array}$ & $\begin{array}{l}\text { Duloxetine } 60 \mathrm{mg}: 4.3 \\
\text { Duloxetine } 120 \mathrm{mg}: 12.1\end{array}$ & 16266355 \\
\hline \multicolumn{9}{|l|}{ Venlafaxine } \\
\hline $\begin{array}{l}\text { Zimmermann et al. } \\
2016\end{array}$ & $\begin{array}{l}\text { Parallel-group } \\
\text { Multicenter }\end{array}$ & $\begin{array}{l}\text { Venlafaxine } 75 \text { mg/day (25) } \\
\text { Placebo (25) }\end{array}$ & $\begin{array}{l}\text { Throughout } \\
\text { chemotherapy }\end{array}$ & $\begin{array}{l}\text { Chemotherapy- } \\
\text { induced peripheral } \\
\text { neuropathy }\end{array}$ & $\begin{array}{l}\text { No sufficient detail on frequencies } \\
\text { of patients with TEAEs }\end{array}$ & 0.0 & 0.0 & 26248652 \\
\hline $\begin{array}{l}\text { Durand et al. } \\
2012\end{array}$ & $\begin{array}{l}\text { Parallel-group } \\
\text { Multicenter }\end{array}$ & $\begin{array}{l}\text { Venlafaxine } 75 \text { mg/day (24) } \\
\text { Placebo (24) }\end{array}$ & 11 days & $\begin{array}{l}\text { Chemotherapy- } \\
\text { induced peripheral } \\
\text { neuropathy }\end{array}$ & $\begin{array}{l}\text { Any (UK) } \\
\text { Nausea (43.1)* } \\
\text { Fatigue / Drowsiness (39.2)* } \\
\text { Vomiting (19.6)* }\end{array}$ & 0.0 & 16.7 & 21427067 \\
\hline $\begin{array}{l}\text { Amr et al. } \\
2010\end{array}$ & $\begin{array}{l}\text { Parallel-group } \\
\text { Monocenter }\end{array}$ & $\begin{array}{l}\text { Venlafaxine ER } 37.5 \text { mg/day (50) } \\
\text { Gabapentin } 300 \text { mg/day (50) } \\
\text { Placebo (50) }\end{array}$ & 10 days & $\begin{array}{l}\text { Post-traumatic } \\
\text { neuropathic pain }\end{array}$ & $\begin{array}{l}\text { No sufficient detail on frequencies } \\
\text { of patients with TEAEs }\end{array}$ & UK & UK & 20473044 \\
\hline $\begin{array}{l}\text { Yucel et al. } \\
2005\end{array}$ & $\begin{array}{l}\text { Parallel-group } \\
\text { Monocenter }\end{array}$ & $\begin{array}{l}\text { Venlafaxine } 75 \text { mg/day (19) } \\
\text { Venlafaxine } 150 \text { mg/day (17) } \\
\text { Placebo (19) }\end{array}$ & 8 weeks & $\begin{array}{l}\text { Various neuropathic } \\
\text { pain }\end{array}$ & $\begin{array}{l}\text { No sufficient detail on frequencies } \\
\text { of patients with TEAEs }\end{array}$ & UK & $\begin{array}{l}\text { Venlafaxine } 150 \mathrm{mg}: 17.6 \\
\text { Venlafaxine } 75 \mathrm{mg}: 5.3\end{array}$ & 15979021 \\
\hline $\begin{array}{l}\text { Tasmuth et al. } \\
2002\end{array}$ & $\begin{array}{l}\text { Crossover-group, } \\
\text { Monocenter }\end{array}$ & $\begin{array}{l}\text { Venlafaxine } 18.75 \text { until } 75 \mathrm{mg} / \mathrm{day} \text { (13) } \\
\text { Placebo (13) }\end{array}$ & 4 weeks & $\begin{array}{l}\text { Neuropathic cancer } \\
\text { pain }\end{array}$ & $\begin{array}{l}\text { Any (UK) } \\
\text { Fatigue (69.2) \# }\end{array}$ & UK & 6.7 & 11888224 \\
\hline
\end{tabular}




\begin{tabular}{|c|c|c|c|c|c|c|c|c|}
\hline & & & & & \begin{tabular}{|l|} 
Dry mouth (61.5) \# \\
Sweating (61.5) \# \\
Headache (46.2) \# \\
Constipation (30.8) \# \\
Nausea (30.8) \# \\
Loss of appetite (23.1) \# \\
Palpitation (23.1) \# \\
Nightmares (15.4) \# \\
Difficult to urinate (15.4) \#
\end{tabular} & & & \\
\hline \multicolumn{9}{|l|}{\begin{tabular}{|l|} 
Milnacipran \\
\end{tabular}} \\
\hline \begin{tabular}{|l} 
Marks et al. \\
2014
\end{tabular} & $\begin{array}{l}\text { Parallel-group } \\
\text { Monocenter }\end{array}$ & $\begin{array}{l}\text { Milnacipran } 100 \text { - } 200 \mathrm{mg}(7) \\
\text { Placebo (4) }\end{array}$ & 10 weeks & Radiculopathy & \begin{tabular}{|l} 
Any (UK) \\
Headache (28.6) \# \\
Constipation (28.6) \# \\
Nausea (14.3) \# \\
Dizziness (14.3) \# \\
Elevated blood pressure (14.3) \# \\
Palpitations (14.3) \# \\
Dyspepsia (14.3) \# \\
Urinary hesitancy (14.3) \# \\
Drowsiness (14.3) \#
\end{tabular} & UK & 28.7 & 25664215 \\
\hline \multicolumn{9}{|l|}{ Amitriptyline } \\
\hline \begin{tabular}{|l} 
Vanelderen et al. \\
2015
\end{tabular} & \begin{tabular}{|l} 
Parallel-group \\
Monocenter
\end{tabular} & $\begin{array}{l}\text { Amitriptyline 25mg/day (20) } \\
\text { Placebo (20) }\end{array}$ & 2 weeks & Radiculopathy & $\begin{array}{l}\text { Any (10.0) \# } \\
\text { Nausea/vomiting (5.0) \# } \\
\text { Rash (5.0) \# }\end{array}$ & UK & 10.0 & 25373391 \\
\hline
\end{tabular}




\begin{tabular}{|c|c|c|c|c|c|c|c|c|}
\hline $\begin{array}{l}\text { Mishra et al. } \\
2012\end{array}$ & $\begin{array}{l}\text { Parallel-group } \\
\text { Multicenter }\end{array}$ & $\begin{array}{l}\text { Amitriptyline } 50-100 \mathrm{mg} / \mathrm{day}(30) \\
\text { Gabapentin } 900-1800 \mathrm{mg} / \mathrm{day}(30) \\
\text { Pregabalin } 150-600 \mathrm{mg} / \mathrm{day}(30) \\
\text { Placebo (30) }\end{array}$ & 4 weeks & $\begin{array}{l}\text { Neuropathic cancer } \\
\text { pain }\end{array}$ & $\begin{array}{l}\text { Any (UK) } \\
\text { No sufficient detail on frequencies } \\
\text { of patients with TEAEs }\end{array}$ & UK & UK & \begin{tabular}{|l|l}
21745832 \\
\end{tabular} \\
\hline $\begin{array}{l}\text { Kautio et al. } \\
2009\end{array}$ & $\begin{array}{l}\text { Parallel-group } \\
\text { Monocenter }\end{array}$ & $\begin{array}{l}\text { Amitriptyline } 25-100 \text { mg/day (58) } \\
\text { Placebo (56) }\end{array}$ & $\begin{array}{l}\text { Throughout } \\
\text { chemotherapy }\end{array}$ & $\begin{array}{l}\text { Chemotherapy- } \\
\text { induced peripheral } \\
\text { neuropathy }\end{array}$ & $\begin{array}{l}\text { Any (UK) } \\
\text { Fatigue (19.0) \# } \\
\text { Dry mouth (UK) } \\
\text { Visual disturbances (UK) } \\
\text { Constipation (UK) }\end{array}$ & UK & UK & 19596934 \\
\hline $\begin{array}{l}\text { Kautio et al. } \\
2008\end{array}$ & $\begin{array}{l}\text { Parallel-group } \\
\text { Monocenter }\end{array}$ & $\begin{array}{l}\text { Amitriptyline 10-50 mg/day (22) } \\
\text { Placebo (22) }\end{array}$ & 12 weeks & $\begin{array}{l}\text { Chemotherapy- } \\
\text { induced peripheral } \\
\text { neuropathy }\end{array}$ & No safety & No safety & No safety & 17980550 \\
\hline $\begin{array}{l}\text { Ho et al. } \\
2008\end{array}$ & $\begin{array}{l}\text { Parallel-group } \\
\text { Monocenter }\end{array}$ & $\begin{array}{l}\text { Amitriptyline 5\% gel (35) } \\
\text { Lidocaine 5\% gel (35) } \\
\text { Placebo (35) }\end{array}$ & 1 week & $\begin{array}{l}\text { Various neuropathic } \\
\text { pain }\end{array}$ & $\begin{array}{l}\text { Only for Amitriptyline group } \\
\text { Any (18.8) \# } \\
\text { Itching (31.4) \# }\end{array}$ & UK & $\begin{array}{l}\text { Only for amitriptyline } \\
0.0\end{array}$ & 18180637 \\
\hline $\begin{array}{l}\text { Lynch et al. } \\
2005\end{array}$ & $\begin{array}{l}\text { Parallel-group } \\
\text { Multicenter }\end{array}$ & $\begin{array}{l}\text { Topical 2\% amitriptyline (22) } \\
\text { Topical 1\% ketamine (22) } \\
\text { Topical 2\% amitriptyline-1\% ketamine (23) } \\
\text { Placebo (25) }\end{array}$ & 3 weeks & $\begin{array}{l}\text { Various neuropathic } \\
\text { pain }\end{array}$ & $\begin{array}{l}\text { Only amitriptyline group } \\
\text { Any }(26.0) \text { ns } \\
\text { No TEAE } \geq 10 \% \text { of patients }\end{array}$ & UK & 4.5 & \begin{tabular}{|l|l}
15983466 \\
\end{tabular} \\
\hline \multicolumn{9}{|c|}{ Nortriptyline } \\
\hline $\begin{array}{l}\text { Hammack et al. } \\
2002\end{array}$ & $\begin{array}{l}\text { Crossover-group, } \\
\text { Monocenter }\end{array}$ & $\begin{array}{l}\text { Nortriptyline } 100 \text { mg/day (51) } \\
\text { Placebo (51) }\end{array}$ & 4 weeks & $\begin{array}{l}\text { Chemotherapy- } \\
\text { induced peripheral } \\
\text { neuropathy }\end{array}$ & $\begin{array}{l}\text { Any (UK) } \\
\text { Dry mouth }(62.0) * \\
\text { Dizziness }(49.0) * \\
\text { Constipation }(41.0) *\end{array}$ & UK & 3.9 & 12098632 \\
\hline
\end{tabular}




\begin{tabular}{|c|c|c|c|c|c|c|c|c|}
\hline $\begin{array}{l}\text { Holbech et al. } \\
2015\end{array}$ & $\begin{array}{l}\text { Crossover-group, } \\
\text { Monocenter }\end{array}$ & $\begin{array}{l}\text { Imipramine } 75 \text { mg/day (18) } \\
\text { Pregabalin } 600 \text { mg (18) } \\
\text { Placebo (19) }\end{array}$ & 5 weeks & $\begin{array}{l}\text { Various neuropathic } \\
\text { pain }\end{array}$ & $\begin{array}{l}\text { Only Imipramine group } \\
\text { Any (43.0) \# } \\
\text { Dry mouth (22.0) \# } \\
\text { Sweating (20.0) \# } \\
\text { Dizziness (10.0) \# }\end{array}$ & \begin{tabular}{|l|} 
UK \\
\end{tabular} & $\begin{array}{l}\text { Only imipramine } \\
17.0\end{array}$ & 25719617 \\
\hline \multicolumn{9}{|c|}{ Escitalopram } \\
\hline $\begin{array}{l}\text { Otto et al. } \\
2008\end{array}$ & $\begin{array}{l}\text { Crossover-group, } \\
\text { Multicenter }\end{array}$ & $\begin{array}{l}\text { Escitalopram 10-20 mg/day (48) } \\
\text { Placebo (48) }\end{array}$ & 6 weeks & $\begin{array}{l}\text { Various neuropathic } \\
\text { pain }\end{array}$ & $\begin{array}{l}\text { Any (51.2) \# } \\
\text { Abdominal discomfort (14.6) \# } \\
\text { Nausea/vomiting (14.6) \# }\end{array}$ & \begin{tabular}{|l|} 
UK \\
\end{tabular} & \begin{tabular}{|l|}
10.4 \\
\end{tabular} & \begin{tabular}{|l|l|l}
1854727 \\
\end{tabular} \\
\hline
\end{tabular}

Table 3: Summary table for antidepressants

TEAE, treatment-emergent adverse event; ER, extended-release; SAEs, serious adverse event; UK, unknown.

Route of administration is not provided when administered orally.

* Statistically different from placebo; ns, no statistical difference from placebo; \#, no statistical comparison to placebo 


\section{PUBMED extraction : 2,148 publications}

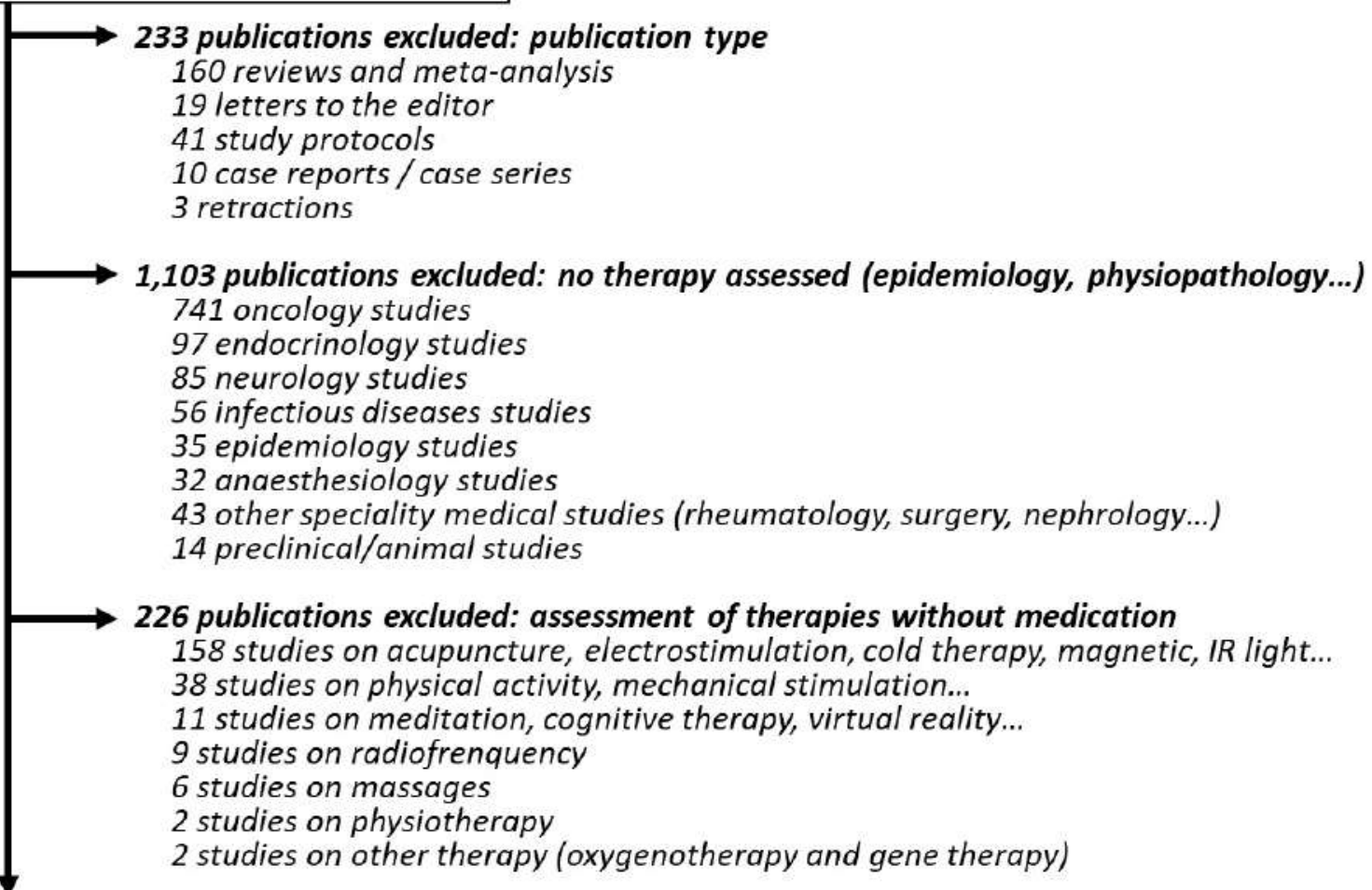

\section{Selection of $\mathbf{5 8 6}$ publications : clinical trials on medications}

\section{4 publications excluded: methodology type and objectives}

99 open label studies

71 studies with no placebo or active control

33 not randomized studies

9 studies on drug combinations

7 studies on acute/subacute treatments

62 phase 1 / healthy volunteer studies

35 studies on central pain or not peripheral neuropathic pain

8 studies on pharmacokinetic

170 publications excluded: other drugs

2 publications excluded: full-text not found 